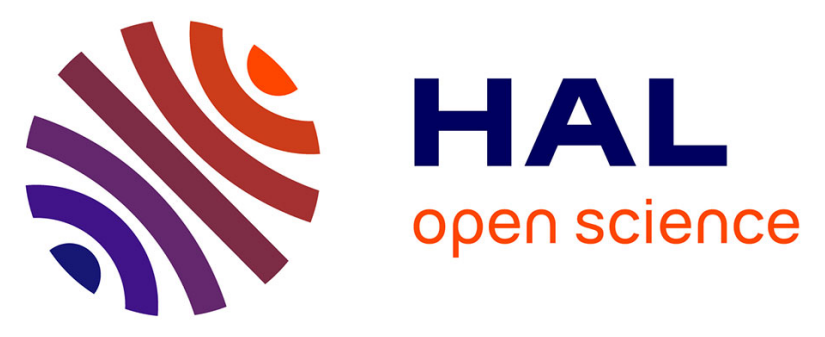

\title{
Iron mineralogy as a fingerprint of former steelmaking activities in river sediments
}

\author{
Hussein Jaafar Kanbar, Emmanuelle Montargès-Pelletier, Benoit Losson, \\ Isabelle Bihannic, Renaud Gley, Allan Bauer, Frédéric Villiéras, Luc Manceau, \\ Antoine G. El Samrani, Veronique Kazpard, et al.
}

\section{To cite this version:}

Hussein Jaafar Kanbar, Emmanuelle Montargès-Pelletier, Benoit Losson, Isabelle Bihannic, Renaud Gley, et al.. Iron mineralogy as a fingerprint of former steelmaking activities in river sediments. Science of the Total Environment, 2017, 599-600, pp.540 - 553. 10.1016/j.scitotenv.2017.04.156 . hal-01542484

\section{HAL Id: hal-01542484 \\ https://hal.univ-lorraine.fr/hal-01542484}

Submitted on 17 Nov 2020

HAL is a multi-disciplinary open access archive for the deposit and dissemination of scientific research documents, whether they are published or not. The documents may come from teaching and research institutions in France or abroad, or from public or private research centers.
L'archive ouverte pluridisciplinaire HAL, est destinée au dépôt et à la diffusion de documents scientifiques de niveau recherche, publiés ou non, émanant des établissements d'enseignement et de recherche français ou étrangers, des laboratoires publics ou privés.

\section{(c)(1)}

Distributed under a Creative Commons Attribution| 4.0 International License 


\title{
Iron Mineralogy as A Fingerprint of Former Steelmaking Activities in River Sediments
}

\author{
Hussein Jaafar Kanbar ${ }^{\mathrm{a}, \mathrm{b}, \mathrm{c}^{*}}$, Emmanuelle Montargès-Pelletier ${ }^{\mathrm{a}, \mathrm{b}^{*}}$, Benoit Losson ${ }^{\mathrm{d}}$, Isabelle Bihannic ${ }^{\mathrm{a}, \mathrm{b}}$, Renaud \\ Gley $^{\mathrm{a}, \mathrm{b}}$, Allan Bauer ${ }^{\mathrm{a}, \mathrm{b}}$, Frederic Villieras ${ }^{\mathrm{a}, \mathrm{b}}$, Luc Manceau ${ }^{\mathrm{d}}$, Antoine G El Samrani ${ }^{\mathrm{c}}$, Veronique Kazpard ${ }^{\mathrm{c}}$, \\ Laurence Mansuy-Huault ${ }^{\mathrm{a}, \mathrm{b}}$ \\ ${ }^{a}$ CNRS, LIEC (Laboratoire Interdisciplinaire des Environnements Continentaux), LTER Zone Atelier Moselle, \\ 54500 Vandœuvre-lès-Nancy, France. \\ ${ }^{\mathrm{b}}$ Université de Lorraine, LIEC (Laboratoire Interdisciplinaire des Environnements Continentaux), UMR 7360, \\ 54500 Vandœuvre-lès-Nancy, France. \\ ${ }^{\mathrm{c}}$ Research and Analysis Platform for Environmental Sciences (PRASE), Doctoral School of Sciences and \\ Technology (EDST); Faculty of Sciences; Lebanese University, P.O. 5, Rafic Hariri Campus, 1003 Hadat, \\ Lebanon. \\ ${ }^{\mathrm{d}}$ Université de Lorraine, LOTERR, UFR SHS-Metz, Ile du Saulcy, CS60228, 57045 Metz cedex 01, France. \\ * Corresponding authors: Hsen.kanbar@gmail.com; emmanuelle.montarges@univ-lorraine.fr
}

\begin{abstract}
Submerged sediment cores were collected upstream of a dam in the Orne River, northeastern France. This dam was built in the context of steelmaking to constitute a water reservoir for blast furnace cooling and wet cleaning of furnace smokes. The dam also enhanced sediment deposition in the upstream zone. This study was performed to unravel the contamination status of sediments and to evidence possible contribution sources. The sediment layers were analyzed for water content, grain size, chemical composition, crystalline phases at a bulk scale and poorly crystalline and amorphous phases at a submicrometer scale. Visual aspect, texture, color, and chemical and mineralogical analyses showed that the settled sediments were mainly composed of fine black matter, certainly comprising steelmaking by-products. Those materials were highly enriched with $\mathrm{Fe}, \mathrm{Zn}, \mathrm{Pb}$ and other trace metals, except for a relatively thin layer of surficial sediments that had settled more recently. Bulk mineralogy revealed crystalline iron minerals, such as magnetite, goethite, wuestite and pyrite, in the deep layers of the sediment cores. Furthermore, microscopic investigations evidenced the presence of ferrospheres, goethite nanoparticles and newly formed Fe-aluminosilicates; all originating from the former steelmaking facilities. The variation of iron mineralogy, combined with specific chemical profiles and other sediment features, demonstrate the different contributions that constitute the sediment deposit. Furthermore, chemical and mineralogical features of goethite and Fe-aluminosilicates could be used as a fingerprint for such contaminated sediments.
\end{abstract}

Keywords: Sediment archives, Steelmaking sludge, Iron Mineralogy, Fealuminosilicates.

\section{Introduction}


River sediments are recognized as reservoirs of various pollutants, such as chemical (e.g. nitrates, pesticides, medical drugs, organic micropollutants and metals) and microbiological (e.g. viruses, bacteria and parasites) (Droppo et al., 2009; Grabowski et al., 2011 and references therin; Heise and Förstner, 2007; Hudson-Edwards et al., 2008). Furthermore, surface waters are often the common receptacle of anthropogenic pollutants from diverse origins, which once combined to particulate matter, might settle and enrich the sediment compartment. A concern could arise if contaminated sediments are then translocated further downstream, which might be caused during specific seasonal or hydroclimatic events (Droppo et al., 2009). It is also commonly assumed that the contaminants in sediments can be several orders of magnitude higher than in the overlying water, and consequently constitute a threat for stream quality (Cappuyns et al., 2006; Simpson et al., 1998). In European and North-American countries, studies dealing with sediment cores have shown that contaminant inputs into sediments were maximized in the 1960s, and then decreased due to the improvement in environmental regulations (Ayrault et al., 2012; Dhivert et al., 2016; Ferrand et al., 2012; Wakeham et al., 2004).

Northern and northeastern France had been very active with mining (such as iron, coal and salt) and metallurgical (such as $\mathrm{Zn}$ and Fe) activities during the last century (Lesven et al., 2010; Lourino-Cabana et al., 2010; Montargès-Pelletier et al., 2014, 2007, Sterckeman et al., 2002, 2000). Industrial facilities were commonly established close to rivers to ensure a water source for the cooling of furnaces. This was the case in Lorraine, where several rivers in the Moselle watershed, like the Orne, Fensch and Rosselle Rivers, were physically, chemically and biologically modified by steelmaking activities, including iron ore mining and coke production (Garcier, 2007; Picon, 2014). Because they were strongly impacted by the industrial activity, those small valleys were referred to as "steelmaking valleys". Waste products, furnace smokes, dust and sludge from wet cleaning of furnace smokes had been introduced in the aqueous media, transported as suspended particulate matter (SPM) or stored more or less definitely in river sediments. The possible metal release due to re-suspension upon flooding (Vdović et al., 2006; Zebracki, 2008) or sediment dredging (Lesven et al., 2010), as well as selective remobilization of metal bearing phases (Montargès-Pelletier et al., 2014) were studied and reported to evidence the possible impact of contaminated sediments. Furthermore, polluted sediment remobilization was shown to cause socioeconomic, ecological and environmental problems (e.g. Fernandes et al., 2016; Macklin et al., 1997; Maclin and Sicchio, 1999). For example, the removal of the Fort Edward Dam (Hudson River) 
caused the remobilization of polluted sediments for tens of kilometers in the downstream area. As a result, more than 40 distinct "polluted sites" had formed and the biota and water quality were severely damaged for a period of nearly thirty years (Maclin and Sicchio, 1999).

Many studies focused on speciation and evolution of elements in contaminated river sediments (e.g. Dewit et al., 2010; Roberts et al., 2002; Spadini et al., 2003; Sterckeman et al., 2000; Zeng et al., 2013), or the speciation of metals in weathered blast furnace sludge from landfills or ponds (e.g. Huot et al., 2013; Kretzschmar et al., 2012; Mansfeldt and Dohrmann, 2004). In order to understand the fate of steelmaking by-products, there is a need for detailed knowledge of the raw materials used, the processes undertaken, and the possible ageing and transformations taking place within the sediment matrix. Therefore, this study focuses on the mineralogy of river sediments that have accumulated upstream of a dam in an area that was highly influenced by steelmaking processes during the last century. The objectives of the study are to i) characterize the sediments that had settled upstream of the dam, ii) identify the layers and phases of lithogenic and anthropogenic sources and iii) follow the Fe-bearing mineral species in the vertical sediment profile. For that purpose, the present study investigates global parameters, chemical composition, as well as iron mineralogy of the sediments. The objectives are attained by using a combination of techniques, mainly X-ray diffraction and scanning and transmission electron microscopies.

\section{Materials and Methods}

\subsection{Study area}

During the $\mathrm{XX}^{\text {th }}$ century, steelmaking activities were very intense in the Lorraine region, and in 1938, as much as $67 \%$ of the total French steel was produced in Lorraine. In 1974, when the French steel production was at its maximum (25 million tons per year "Mt/yr"), the production in Lorraine was about $8 \mathrm{Mt} / \mathrm{yr}$. The steel or iron basin in Lorraine covered a $60 \mathrm{~km}$ long and $40 \mathrm{~km}$ wide area, subdivided into several compartments, one of which was the Orne valley. The Orne River, a tributary of the Moselle River, flows in northeastern France (Figure $1 \mathrm{a}$ ), is $90 \mathrm{~km}$ long, has a drainage basin of 1,226 km $\mathrm{km}^{2}$, and displays a mean discharge of $12.2 \mathrm{~m}^{3} / \mathrm{s}$ at the junction with the Moselle River. Several small sized dams were built on the Orne River to create water reservoirs for industrial purposes.. The production of steel encountered the highest expansion period from 1954 to 1960. Thus, at the end of the 50's, two new blast furnaces were installed on the left bank of the Orne River, located within the limits of Moyeuvre-Grande city area, and close to the iron mine of Jœuf 
«Mine du Haut Fond» (Figure 1 b). Those two blast furnaces were active from 1960 until 1988, with a steel production of about 1.3 Mt/yr (Freyssenet, 1979). In the same period, Beth dam was built to provide high volumes of water for the general functioning of steelmaking facilities (Figure $1 \mathrm{~b}$ and Supplementary Material "SM"). Two other sets of blast furnaces were previously installed along the Orne River, one set at the exit of Jœuf city (active from 1882 to 1970), and another set in the center of Moyeuvre-Grande city (active from 1918 to 1975) (Figure 1 b).. The blast furnaces were fed with ore extracted from the nearby iron mine; the ore was partially sintered before its introduction in the furnace (about $64 \%$ in 1967), producing about $2.4 \mathrm{Mt} / \mathrm{yr} . ” 1)$.

Generally speaking, for this part of the Orne valley, the steelmaking activities and related industrial activities (iron mining, coke and gas production) resulted in a strong

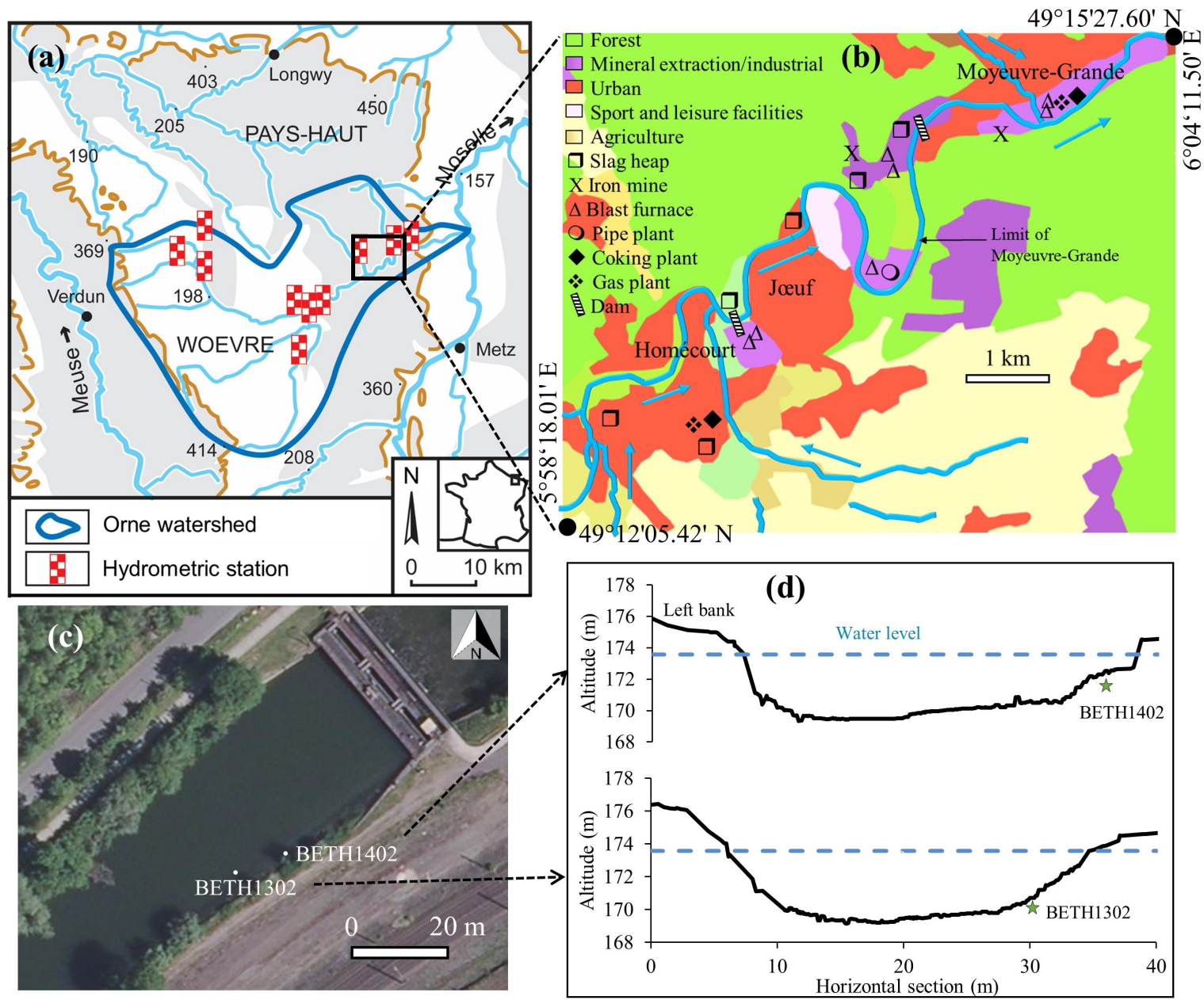

Figure 1: a: The Orne watershed located northeastern France. Map created on the basis of data provided by the French National Institute of Geography IGN, www.geoportail.gouv.fr, b: the Orne River section that was studied, the land use established in 2006 (Corine Land Cover 2006) and the former locations of industrial facilities, c: location of the cores and $d$ : the profiles of the riverbeds where the cores were collected. The profiles were produced using an echo sounder. 
contamination of soils and aqueous media, with the spreading of materials enriched in iron, other metallic elements and persistent organic pollutants, such as polycyclic aromatic hydrocarbons (PAHs). In 1988, dredging of the Orne River was performed from Jœuf to Moyeuvre, stopping at the limit of Moyeuvre city area. Thus, that dredging operation removed most of the highly contaminated sediments (Garcier, 2007; Picon, 2014), but did not concern the sediment deposits in the upstream part of the Beth dam. This dam should be partially modified or completely removed in the coming decade, with consequent questioning about the fate of the highly anthropogenic sediments located on the right bank of the river.

\subsection{Sediment coring}

Three sediment cores were collected at distinct locations upstream of the Beth dam. The lengths of the cores were 96 (BETH1302), 131 (BETH1402) and $18 \mathrm{~cm}$ (BETH1507). The submerged sediments were cored with a piston corer (or Beeker corer) directly from the bank (in July 2013, the dam was emptied for three days), or from a floating platform (2014 and 2015 coring, Quadriraft from GEHCO laboratory, Tours University, France). BETH1402 and BETH1302 cores were 2 and $4 \mathrm{~m}$ away from the right bank, respectively (Figure 1: $\mathrm{c}-\mathrm{d}$ ). Most analyses were performed on BETH1402 core $(131 \mathrm{~cm})$. In addition, the purpose of the third core (BETH1507) was to check the thickness of recent sediments lying above the highly contaminated sediments by steelmaking waste on one hand, and also to estimate the longitudinal extent of this sediment deposit.

\subsection{Sample preparation for analyses}

The collected sediment cores were sealed from air and transported back to the laboratory in a vertical position. It should be noted that the visual aspect of BETH1402 core was rather homogeneous along the $131 \mathrm{~cm}$ of extracted matter, with no eye detectable variation along the sediment profile, except for brown colored materials found at the surface $(11 \mathrm{~cm})$. Furthermore, the uppermost $2 \mathrm{~cm}$ layer was highly loose and muddy, and thus was taken as the surface layer. Afterwards, $3 \mathrm{~cm}$ thick layers were taken. For each layer, a small aliquot was then frozen at $-80{ }^{\circ} \mathrm{C}$ for microscopic and spectroscopic analyses; another aliquot was put in pre-weighed containers, frozen, freeze-dried and a part was ground using an agate mortar and pestle.

\subsection{Physical properties of sediments}


For each layer, the water content was calculated by the difference in mass between the fresh and the freeze-dried samples. Also, a raw aliquot (not ground) of the freeze-dried aliquot was used to determine the particle size distribution (PSD) by laser diffraction (Sympatec GmbH, LIEC). The sample was gently disaggregated using a plastic spatula and introduced into the Sucell dispersing unit (containing distilled water) where the sample was circulating and being ultra-sonicated for 60 seconds. Duplicate or triplicate measurements were performed to improve the measurement quality. The particle size distribution was then represented as volumetric percentage as a function of particle diameter. In addition, the percentiles $(\mathrm{D} i)$ of the particles were calculated using Helos software. $\mathrm{D}_{i}$ is the $i^{\text {th }}$ percentile, i.e. the particle's diameter at which $i \%$ of the particles in the sample is smaller than $\mathrm{D}_{i}$ (in $\mu \mathrm{m})$.

\subsection{Sediment dating, measurements of ${ }^{137} \mathrm{Cs}$ and excess ${ }^{210} \mathrm{~Pb}$}

Dating of sediment layers was performed using the ${ }^{210} \mathrm{~Pb}$ and ${ }^{137} \mathrm{Cs}$ methods (Appleby and Oldfield, 1992; Radakovitch et al., 1999; Robbins and Edgington, 1975). Freeze-dried and powdered sediment samples were packed into 15 or $60 \mathrm{ml}$ (depending on the sediment quantity available) pre-tared polyethylene specimen cups and sealed. ${ }^{137} \mathrm{Cs}(661.6 \mathrm{keV})$ and ${ }^{210} \mathrm{~Pb}(46.5 \mathrm{keV})$ activities were determined by gamma spectrometry using the seven very low-background coaxial N- and P-type GeHP detectors (Canberra/Ortec) available at the LSCE (Laboratoire des Sciences du Climat et de l'Environnement, CEA CNRS, UVSQ, Gif sur Yvette, France). "Excess" ${ }^{210} \mathrm{~Pb}\left({ }^{210} \mathrm{~Pb}_{\mathrm{xs}}\right)$ activity was calculated by subtracting the supported activity (determined using two ${ }^{238} \mathrm{U}$ daughters, i.e. ${ }^{214} \mathrm{~Pb}$, by taking the average count number at 295.2 and $351.9 \mathrm{keV}$, and ${ }^{214} \mathrm{Bi}$ at $609.3 \mathrm{keV}$ ) from the total activity of ${ }^{210} \mathrm{~Pb}$ (Le Cloarec et al., 2011; Lepage et al., 2015). Those analyses were carried out on eleven layers of the BETH1302 core.

\subsection{Chemical composition of sediments}

The freeze-dried and ground aliquots were used for semi-quantitative element analyses using a Niton X-ray fluorescence (XRF) gun (Thermo Scientific Niton XL3t GOLDD+ Analyzer from GeoRessources laboratory, Vandœuvre-lès-Nancy, France) (SM 2 a). XRF and PSD results were used to select the layers for the precise determination of major and trace elements. Major and trace elements were detected by inductively coupled plasma optical emission spectrometry (ICP-OES) and inductively coupled plasma mass spectrometry (ICP-MS), respectively. The quantified elements were $\mathrm{Al}, \mathrm{Ca}, \mathrm{Fe}, \mathrm{K}, \mathrm{Mg}, \mathrm{Mn}, \mathrm{P}, \mathrm{Si}$ and $\mathrm{Ti}$ 
(major elements); As, Ba, Be, Bi, Cd, Co, Cr, Cs, Cu, Ga, Ge, Hf, In, Mo, Nb, Ni, Pb, Rb, Sb, $\mathrm{Sn}, \mathrm{Sr}, \mathrm{Ta}, \mathrm{Th}, \mathrm{U}, \mathrm{V}, \mathrm{W}, \mathrm{Zn}$ and $\mathrm{Zr}$ (trace elements); Ce, Eu, La, Nd, Sm and Pr (light lanthanides), Dy, Er, Gd, Ho, Lu, Tb, Tm and Yb (heavy lanthanides), and Sc and Y (rare earth elements "REE"); in addition to total carbon, organic carbon and sulfur. These analyses were performed at SARM (Service d'Analyse des Roches et des Minéraux - CRPG, Vandœuvre-lès-Nancy, France) and all analytical methods were subject to QC/QA procedures using certified reference materials (Carignan et al., 2001).

\subsection{Mineralogy of sediments}

\subsubsection{Bulk and major mineral phases detected by XRD}

X-ray diffraction (XRD) analyses were performed on the ground sediment layers to determine the major crystalline phases. A D8 Advance Bruker diffractometer with a Co $\mathrm{K}_{\alpha 1}$ radiation source, operated at $35 \mathrm{kV}$ and $45 \mathrm{~mA}(\lambda=1.7902 \AA)$, was used. XRD patterns were collected on the angular range $(2 \theta)$ of $3-64^{\circ}$, with a $0.034^{\circ}$ step size and a $3 \mathrm{sec}$ collecting time. All layers were subjected to XRD analyses, and for clearness purpose, only relevant patterns are presented.

Furthermore, fine particles of sediment layers (from 11 till $131 \mathrm{~cm}$ ) were also investigated from a mineralogical point of view. Indeed, the fingerprint of the former steelmaking industries was shown to be held in the fine particles (as it will be revealed later in the text). That fine fraction is most prone to be remobilized for farther distances under different scenarios, such as high water flow, flooding, dredging and modifying or removing the dam. The fine fraction was extracted from the bulk sample by suspending $1 \mathrm{~g}$ of dry and non-ground sample in $200 \mathrm{ml}$ ultrapure water for 30 minutes. Then ultrasound was applied for 5 - 15 minutes to separate the aggregates, stirred for a few seconds, and left for 4 hours to settle. The supernatant was centrifuged at $34000 \mathrm{~g}$ for 15 minutes, and the resulting solid sample was prepared on glass slides to identify the major crystalline phases of the $<2 \mu \mathrm{m}$ fraction. Due to the low amount of fine material recovered, the XRD patterns were only obtained on oriented preparations.

\subsubsection{Millimetric to sub-micrometric analyses: light microscope, SEM and TEM}

For light microscope observations, a slide of each sediment layer was prepared by dropping a few milliliters of sediment-ultrapure water mixture on a glass slide, which was dried using a hot plate. Light microscope observations were conducted to visualize certain 
particles and phases, such as diatom skeletons, and what later turned out to be distinct iron minerals and framboidal pyrites. The last two phases were detected using dark field mode. In addition, $30 \mu \mathrm{m}$ thick polished thin sections were prepared for several layers of BETH1402 sediment core (GeoRessources laboratory, Vandœuvre-lès-Nancy, France). Dried and nonground samples were used to prepare thin sections for the layers $0-2 \mathrm{~cm}, 14-17 \mathrm{~cm}, 38-$ $41 \mathrm{~cm}, 62-65 \mathrm{~cm}, 104-107 \mathrm{~cm}$ and $125-128 \mathrm{~cm}$. The thin sections were later visualized under a light microscope.

Micrometric particles were identified and characterized using the scanning electron microscope (SEM) Hitachi S-4800 equipped with a Kevex 4850-S energy dispersive X-ray spectrometer (EDXS) (GeoRessources laboratory, Vandœuvre-lès-Nancy, France). Dried sediment particles were taped on metallic holders with carbon tape and were carbon coated. The following layers were analyzed by SEM: $0-2 \mathrm{~cm}, 8-11 \mathrm{~cm}, 11-14 \mathrm{~cm}, 14-17 \mathrm{~cm}$, $41-44 \mathrm{~cm}$ and $125-128 \mathrm{~cm}$. In addition, thin section of the layer $125-128 \mathrm{~cm}$ was also observed via SEM. The accelerating voltage was set to $15 \mathrm{kV}$; when a better resolution was required, the accelerating voltage was set to $3 \mathrm{kV}$. For EDXS, the acquisition time was set to 60 seconds.

Transmission electron microscopy (TEM) was used to investigate amorphous and poorly crystalline phases at a sub-micrometric scale. A CM200 Philips TEM with $200 \mathrm{kV}$ accelerating voltage coupled with an EDXS was used in Jean Lamour Institute (Department of Microscopy, Lorraine University, Nancy, France). The samples frozen at $-80{ }^{\circ} \mathrm{C}$ were used for TEM investigations. One to two milligrams of the raw sample were suspended in ethanol and exposed to ultrasound for 10 minutes to disperse the particles. Afterwards, a drop from the suspension was put on a carbon coated copper grid and left to evaporate. EDX spectra were recorded on selected areas using the nano-probe device, and acquisition time was set to 50 or 70 seconds, depending on the particle thickness. Selective area electron diffraction (SAED) patterns were collected for certain nanoparticles, which were predominantly observed in TEM micro-images. The following sediment layers were analyzed using TEM: 0 $-2 \mathrm{~cm}, 2-5 \mathrm{~cm}, 5-8 \mathrm{~cm}, 11-14 \mathrm{~cm}, 14-17 \mathrm{~cm}, 41-44 \mathrm{~cm}, 62-65 \mathrm{~cm}, 104-107 \mathrm{~cm}$ and $125-128 \mathrm{~cm}$. Furthermore, TEM was also used to investigate the fine fraction (as prepared in section 2.7.1).

\section{Results}

\subsection{Visual description, water content and grain size of the sediments}


For all sediment cores, a clear distinction could be made between two types of settled materials; the top layers appeared to be brown colored materials, overlying black and fine sediments. This was observed for the three cores collected in the upstream area of the Beth dam. The thickness of the brownish surface sediments varied as follow; $28 \mathrm{~cm}$ for BETH1302, $11 \mathrm{~cm}$ for BETH1402 and $3 \mathrm{~cm}$ for BETH1507. For BETH1402 sediments, the water contents of the brownish, loose and muddy top layers $(0-8 \mathrm{~cm})$ were the highest $(\sim 73$ $\%)$, while the water content significantly dropped at the end of the brown zone $(8-11 \mathrm{~cm})$ (Figure $2 \mathrm{a}$ ). Water content further dropped to reach a minimum of $47 \%$ at $68 \mathrm{~cm}$, and finally displayed two slight increasing trends for layers $68-110 \mathrm{~cm}$ and $110-131 \mathrm{~cm}$. This modification of water content could also be due to sediment compaction resulting from gravity coring. Moreover, the sediment layers showed $\mathrm{D}_{50}$ values ranging between 11 and 34 $\mu \mathrm{m}$ (Figure $2 \mathrm{~b}$ ). The size of the carried and subsequently deposited material is relatively fine, not only due to the abatement of water flow influenced by the dam (Fryirs and Brierley, 2012), but also likely related to the industrial origin of the black material.

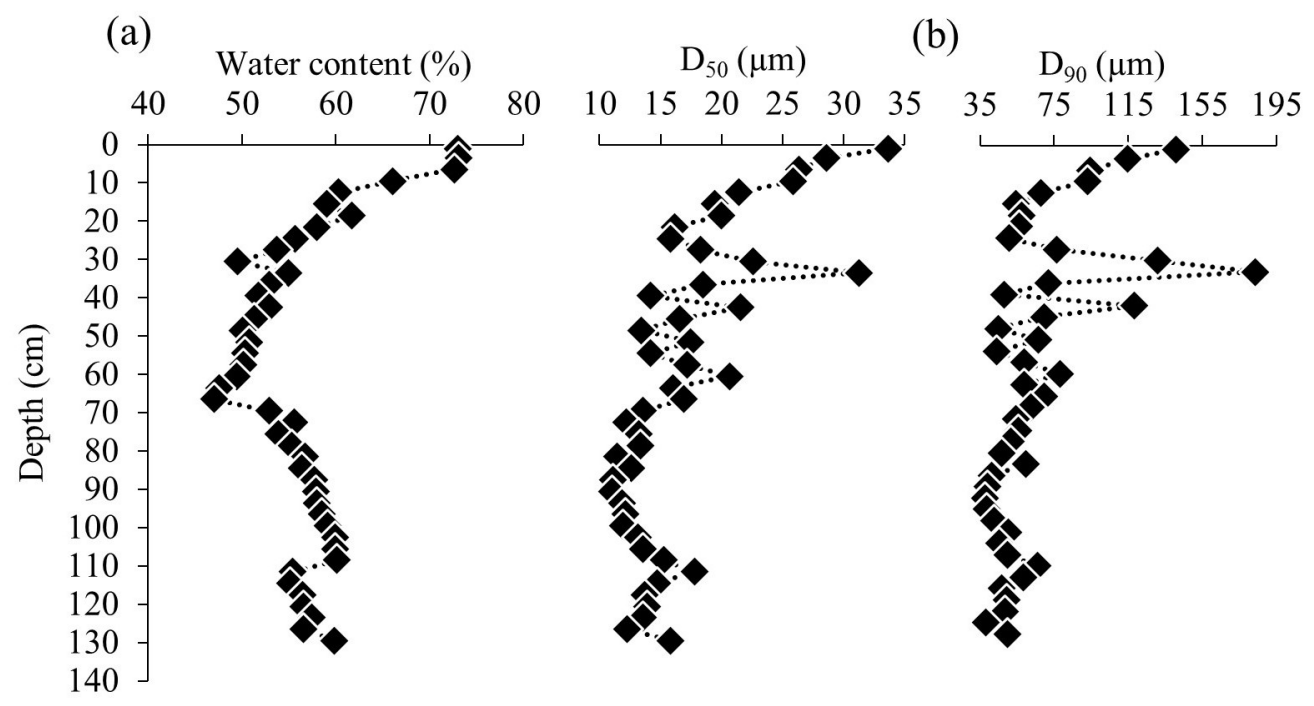

Figure 3: Variation of a: water content (in \%) and $b$ : $D_{50}$ and $D_{90}$ values (in $\mu \mathrm{m}$ ) of sediment particles for BETH1402.

For the top $26 \mathrm{~cm}$ sediments, $\mathrm{D}_{50}$ and $\mathrm{D}_{90}$ values decreased with depth; then relatively coarser particles were detected at $29-35 \mathrm{~cm}$ depth, with a maximum at $33.5 \mathrm{~cm}$ (layer 32 $35 \mathrm{~cm}$ ). Fluctuations of the particle size were also noticed between 35 and $68 \mathrm{~cm}$. The last section of this core $(68-131 \mathrm{~cm})$ contained the finest particles $\left(\mathrm{D}_{50}\right.$ values were as low as 11 $\mu \mathrm{m})$, except for the relatively coarser fraction of $107-116 \mathrm{~cm}$. The layer at $110 \mathrm{~cm}$ depth marked a start of a new sub-zone as evidenced by water content evolution (Figure 2: $a-b$ ). 
On the basis of water content and grain size analyses (Figure 2), three units could be distinguished in the sediment core, which are $0-11 \mathrm{~cm}, 11-68 \mathrm{~cm}$ and $68-131 \mathrm{~cm}$.

\subsection{Dating of Beth sediments}

The measurements of ${ }^{137} \mathrm{Cs}$ and ${ }^{210} \mathrm{~Pb}$ are reported in Figure 3. Due to the similarity of the contents of major elements between the cores BETH1302 and BETH1402, we assumed that the dating results presented for BETH1302 could be applied to BETH1402 (SM 2 b). The measurements were considered to be rather unsucessful due to the relatively low counting of ${ }^{137} \mathrm{Cs}$ and the absence of ${ }^{210} \mathrm{~Pb}_{\mathrm{xs}}$ decrease with depth. Indeed, it was not possible to estimate a sedimentation rate on the basis of those ${ }^{210} \mathrm{~Pb}_{\mathrm{xs}}$ values. Such a method is commonly used to date recent sediment archives

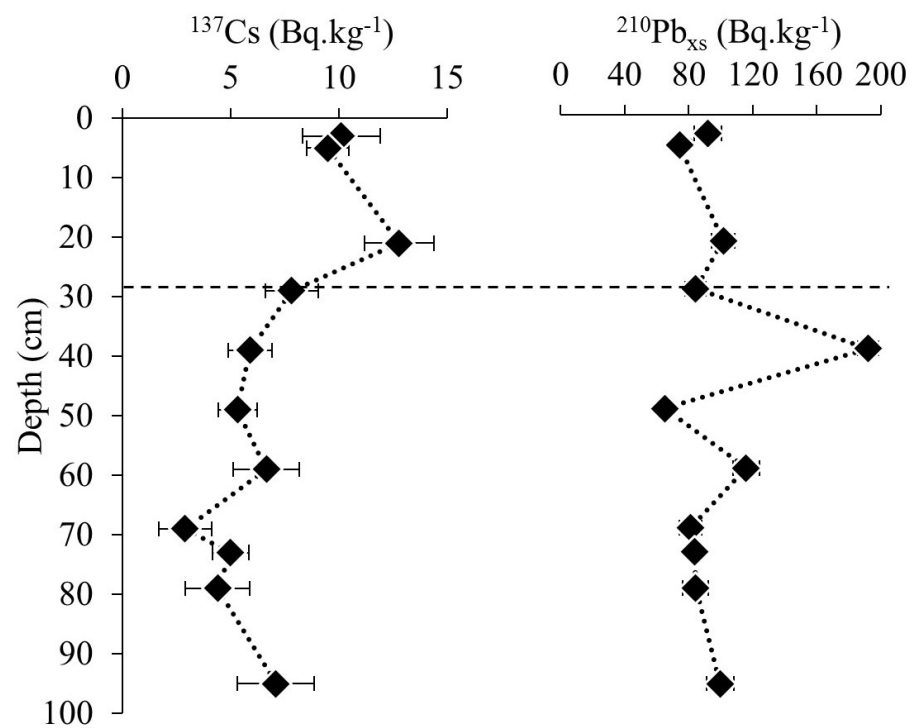
peak as it is usually reported. Two peaks were expected, one due to Figure 4: Radionuclide vertical profiles for ${ }^{210} \mathrm{~Pb}_{\mathrm{xs}}$ and ${ }^{137} \mathrm{Cs}$. The dashed line marks the limit between brown and black sediments.

atmospheric nuclear bomb tests (from

1954 to 1963 with a maximum of ${ }^{137} \mathrm{Cs}$ atmospheric emission in 1963), and a second maximum due to the Chernobyl nuclear plant accident in 1986. Asuming that the atmospheric emissions of ${ }^{137} \mathrm{Cs}$ ceased in 1963, we can suppose that the Beth sediments had majorly settled after the beginning of atmospheric nuclear tests (1954). The expected peak of Chernobyl nuclear plant explosion did not show up either. The presence of ${ }^{137} \mathrm{Cs}$ suggests that the sediments are younger than 1954 which is consistant with the date of Beth dam building. The atmospheric depositions of ${ }^{137} \mathrm{Cs}$ are rapidly followed by run-off of soil matter, and clay minerals (Lepage et al., 2015; Sawhney, 1972) were shown to strongly scavenge this radioactive element, and are readily transported to streams and rivers during rain events. The clay-size fraction $(<2 \mu \mathrm{m})$ of river suspended particulate matter was expected to be 
particularly enriched in ${ }^{137} \mathrm{Cs}$, and the ${ }^{137} \mathrm{Cs}$ content in sediments is definitely depending on the settling rate of those fine particles. The absence of ${ }^{210} \mathrm{~Pb}$ decrease with depth on the other hand might be assigned to the modification of river hydrodynamics and sedimentation regime. ${ }^{137}$ Cs measurements confirmed the age of sediments but a precise age model could not be established.. Taking into account the ${ }^{137} \mathrm{Cs}$ contents and the activity period of the blast furnaces, we assumed that the vertical profile covered the period from 1960 to 2014, and that brown sediments started to settle after the steelmaking activities stopped in 1988.

\subsection{Chemical composition of sediments as a function of depth}

The vertical variations of $\mathrm{Si}, \mathrm{La}, \mathrm{Ca}$ and $\mathrm{Fe}$ contents in the sediment core are shown in Figure $4 \mathrm{a}$. The vertical profiles of light lanthanides other than $\mathrm{La}$ (which are $\mathrm{Ce}, \mathrm{Nd}$ and $\mathrm{Pr}$ ), major elements $\mathrm{K}, \mathrm{Na}$, Ti and $\mathrm{Al}$, and trace element $\mathrm{Zr}$ are plotted in SM 3. It should be noted that $\mathrm{Si}, \mathrm{K}, \mathrm{Na}, \mathrm{Al}, \mathrm{Ti}, \mathrm{Zr}$ and light lanthanides ( $\mathrm{La}, \mathrm{Ce}, \mathrm{Nd}$ and $\mathrm{Pr}$ ) followed a similar trend in the profile of BETH1402 core, and were subsequently classified into one group, referred to as $\mathrm{Si}$ group. Indeed, all those cited elements were significantly correlated to one another (Pearson correlation coefficient "PCC" or Pearson's R 0.9, SM 4). From the vertical profiles of this first set of elements, 4 units could clearly be defined, which are $0-11 \mathrm{~cm}, 11$ $-44 \mathrm{~cm}, 47-68 \mathrm{~cm}$ and $68-131 \mathrm{~cm}$ (indicated as I, II, III and IV, respectively, in Figure 4). The first unit (between 0 and $11 \mathrm{~cm}$ ) was the most enriched with elements of the Si group, suggesting a strong contribution of materials originating from erosion in the watershed. The second unit showed an increasing trend from 11 till $41 \mathrm{~cm}$, a peak at $44-47 \mathrm{~cm}$, a slight decreasing trend for $47-68 \mathrm{~cm}$, and a quasi-stable content for the last unit $(68-131 \mathrm{~cm})$. The layer $44-47 \mathrm{~cm}$ displayed a striking discontinuity for all elements and was therefore considered as an individual layer. Furthermore, the contents of the lanthanides ( $\mathrm{La}, \mathrm{Ce}, \mathrm{Nd}$ and Pr) in the $44-47 \mathrm{~cm}$ layer were very close to those measured in unit I (Figure $4 \mathrm{a}$ and SM 3). Although Si, K and Al contents were high for the $44-47 \mathrm{~cm}$ layer, they did not reach the respective ranges of unit I. Ca contents were relatively high for the $41-44$ and $44-47$ cm layers ( 9.8 and $9.4 \%$, respectively), and similar to lanthanides, the contents were as high as in surface sediments (unit I). Another distinctive sediment feature is the particularly high Fe contents (between 15 and $29 \%$ ), related to the iron mining and steelmaking activities in the vicinity of the river (Figure 4 a). It is worth mentioning that Fe contents in the lower units (II till IV) were 3 to 5 folds higher than the surface unit (unit I). Such high Fe contents were also encountered in the other cores. Fe variation is clearly opposite to the first group of elements with PCC close to -1 (SM 4), and showed a global increase with depth. This allows 
us to define the group of $\mathrm{Si}, \mathrm{K}, \mathrm{Na}, \mathrm{Ti}, \mathrm{Al}, \mathrm{Zr}$ and light lanthanides ( $\mathrm{La}, \mathrm{Ce}, \mathrm{Nd}$ and $\mathrm{Pr}$ ) as a lithogenic group. Those elements mainly originate from watershed surface weathering and soil erosion, and thus reflect the geological background.

Similarly to the iron contents in BETH1402 core, total sulfur, Mn, Mg, P, As, Cd, Co,

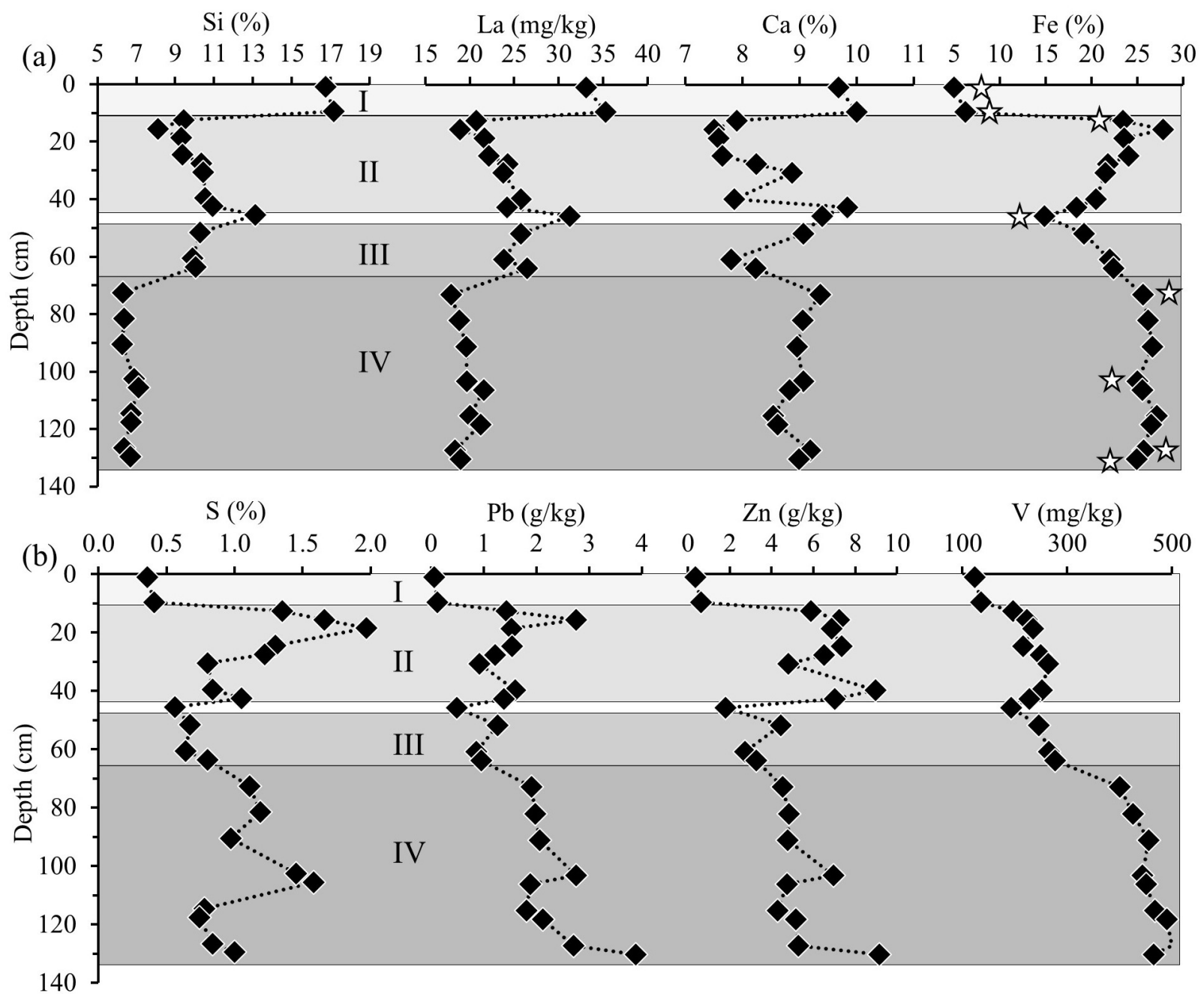

Figure 5: Variation of a: $\mathrm{Si}(\%), \mathrm{La}(\mathrm{mg} / \mathrm{kg}$ ), $\mathrm{Ca}(\%)$ and $\mathrm{Fe}(\%)$; and b: total sulfur (S in \%), $\mathrm{Pb}(\mathrm{g} / \mathrm{kg}), \mathrm{Zn}$ $(\mathrm{g} / \mathrm{kg})$ and $\mathrm{V}(\mathrm{mg} / \mathrm{kg})$ as a function of depth for the sediment layers of BETH1402 core. The units $0-11$ $\mathrm{cm}, 11-44 \mathrm{~cm}, 47-68 \mathrm{~cm}$ and $68-131 \mathrm{~cm}$ are indicated by I, II, III and IV respectively. In the Fe profile, stars are put near the layers for which XRD patterns are presented in the following figure.

$\mathrm{Cr}, \mathrm{Cu}, \mathrm{Mo}, \mathrm{Ni}, \mathrm{Pb}, \mathrm{Sc}, \mathrm{Sb}, \mathrm{Sn}, \mathrm{V}, \mathrm{W}$ and $\mathrm{Zn}$ contents were less enriched in the $0-11 \mathrm{~cm}$ unit; some of them are plotted in Figure 4 b (see also SM 3). Indeed, total sulfur, Cr, Zn and $\mathrm{Pb}$ showed similar behavior and were significantly correlated $(P<0.05)$, except for $\mathrm{Cr}$ and $\mathrm{Pb}(P=0.159)$. Furthermore, those elements were also correlated to Fe $(P<0.01)(\mathrm{SM} 4)$. As for $\mathrm{Pb}$ and $\mathrm{Zn}$, the start of the second unit (i.e. layer $11-14 \mathrm{~cm}$ ) showed a great increase in their contents. The high contents of the "trace" metals $\mathrm{Pb}(0.1-0.4 \%)$ and $\mathrm{Zn}(0.1-0.9$ $\%)$ in the black sediments $(11-131 \mathrm{~cm})$ eliminate the term "trace" and highlight on the level 
of sediment contamination. In our case, enrichment factors for $\mathrm{Pb}$ and $\mathrm{Zn}$ reached as much as 77 and 35 respectively (Al was taken as the "conservative" element and the recently deposited $0-2 \mathrm{~cm}$ layer was taken as reference for the calculation of enrichment factors, i.e. $68 \mathrm{mg} / \mathrm{kg}$ for $\mathrm{Pb}$ and $349 \mathrm{mg} / \mathrm{kg}$ for $\mathrm{Zn}$ ). However, none of the measured elements could be considered as a conservative element in the case of the Beth sediments. Therefore, the differentiation between the lithogenic nature of unit I and the other units (II till IV) is obvious, without a real need of enrichment factor calculation. In such contaminated sediments, aluminum normalization was not relevant due to the drastic decrease of this element with depth (SM 3).

Other trace elements showed relatively striking contents in BETH1402 sediments. Indeed, $\mathrm{V}$ profile displayed a relatively continuous increase with depth (Figure $4 \mathrm{~b}$ ) and was strongly correlated with $\mathrm{Mn}(P<0.01, \mathrm{PCC}=0.956, \mathrm{SM} 4)$. Finally, the four units (as seen in Figure 4 a) could also be distinguished for the elements presented in Figure $4 \mathrm{~b}$ (such as total sulfur, $\mathrm{Zn}$ and $\mathrm{Pb}$ ) and SM 3. Those four units certainly demonstrate a modification of steelmaking activities and processes, and/or a modification of the nature of steelmaking wastes poured into the Orne waters. Iron being the major element brought to the river by the former industrial activities, investigations about its status in the sediments are presented in the following paragraphs.

\subsection{Mineralogy of sediments}

\subsubsection{Major crystalline minerals}

The major crystalline phases were studied through the qualitative analysis of XRD patterns. The sediment cores BETH1302, BETH1402 and BETH1507 showed the same mineralogical composition, and only BETH1402 sediment layers will be discussed here. For clarity, the XRD patterns of distinct layers, namely $0-2 \mathrm{~cm}, 8-11 \mathrm{~cm}, 11-14 \mathrm{~cm}, 44-47$ cm, $68-71 \mathrm{~cm}, 95-98 \mathrm{~cm}, 125-128 \mathrm{~cm}$ and $128-131 \mathrm{~cm}$, are shown in Figure 5. Major crystalline phases, such as quartz, calcite and phyllosilicates were revealed by XRD. The evolution of major elements could be related to the evolution of some major crystalline

phases. Indeed, a great diminution of quartz peaks (reflections at $3.34 \AA$ and $4.26 \AA$ ) could be related to the simultaneous decrease of Si contents from the surficial brown sediments (unit I) to the underlying black sediments (Figure 4 a and insert of Figure 5). Even more, the relatively higher diffraction line intensity for quartz in layer $44-47$ (insert of Figure 5) is coupled to an increase in lithogenic elements, and a decrease in iron and most of the trace 
elements (Figure 4). In addition, diffraction line intensities of quartz indicated a significant decrease between the $125-128 \mathrm{~cm}$ and $128-131 \mathrm{~cm}$ layers, while Si content appeared rather constant.

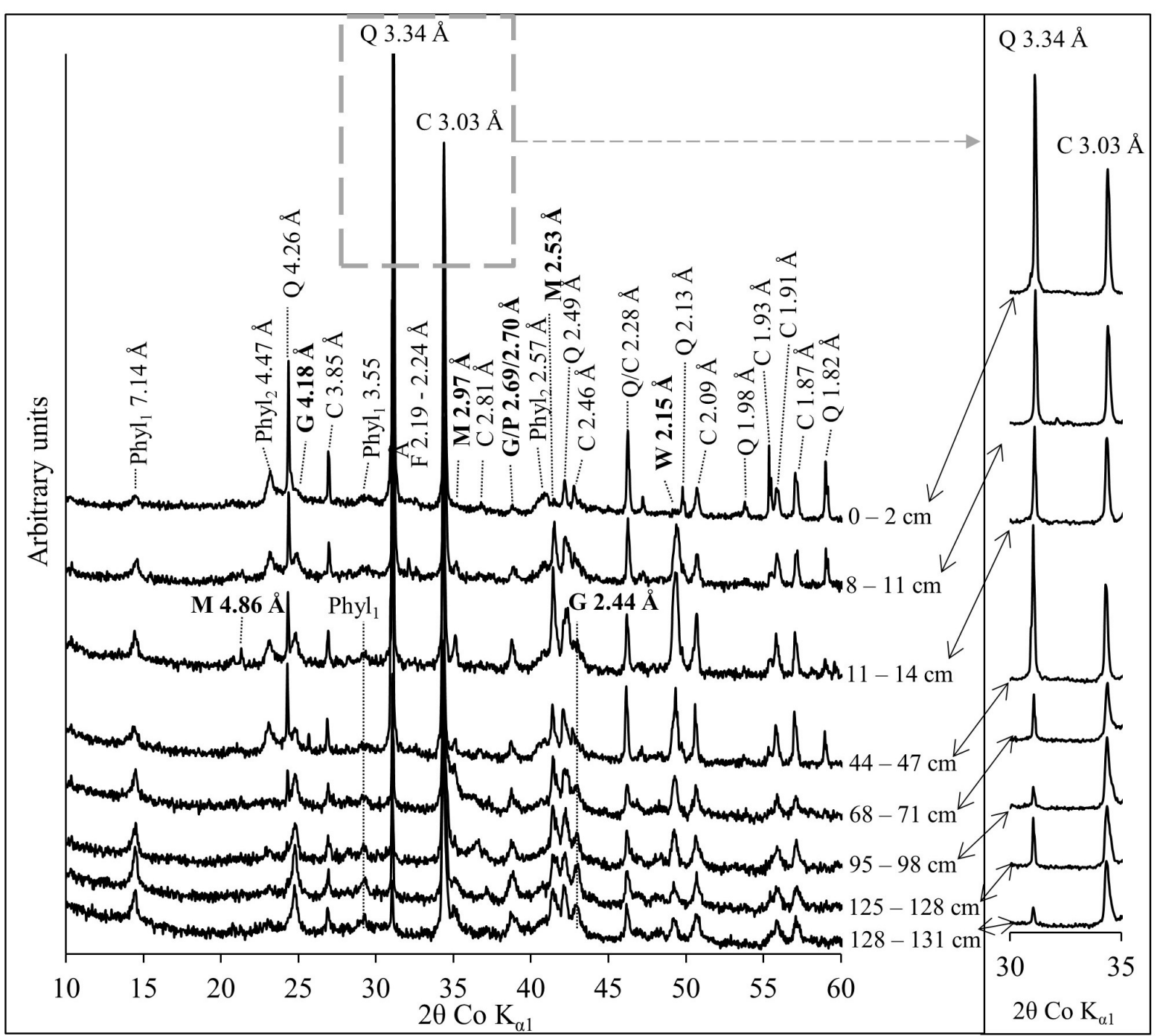

Figure 6: XRD patterns of chosen BETH1402 sediment layers. Phyl: phyllosilicates (including Phyl ${ }_{1}$ and $\mathrm{Phyl}_{2}$, which are treated differently; see text for more information), Q: quartz, G: goethite, C: calcite, M: magnetite, P: pyrite, W: wuestite. Iron minerals are labelled bold. The insert on the right shows the variation of quartz and calcite peak intensities with depth.

Calcite diffraction lines (3.03 $\AA$ and $3.85 \AA$ ) evolved similarly to quartz, showing maximum intensities in the first unit and at the $44-47 \mathrm{~cm}$ layer; and finally a decreasing trend with depth. Even though the Ca content tends to follow the trend displayed by calcite occurrence in the top unit of the core (and for the specific layer $44-47 \mathrm{~cm}$ ), it was not completely correlated to carbonate occurrence as evidenced by XRD. Phyllosilicates were also detected with the basal reflections 001 and the $h k l$ reflections (4.47 and $2.57 \AA$; denoted by $\mathrm{Phyl}_{2}$ in Figure 5). Although phyllosilicates and clay minerals were mainly present in the 0 
$-2 \mathrm{~cm}$ layer of unit I, and slightly present in deeper layers, the intensity of the peak centered at $7.14 \AA$, assigned to $\mathrm{d}(001)$ plane of TO clay, seemed to increase with depth and therefore will be treated differently, along with the diffraction line at $3.55 \AA$ (denoted by $\mathrm{Phyl}_{1}$ in Figure 5). Indeed, the diffraction line at $3.55 \AA$ is related to that of $7.14 \AA$, which is clearly visible in the XRD patterns of layers inferior to $14 \mathrm{~cm}$. The increase of the 7.14 and $3.55 \AA$ peaks were also evidenced for BETH1302 sediment core (SM 5). The apparent increase of the peak at $7.14 \AA$ is not associated with the other expected $h k l$ lines for phyllosilicates (referred to as $\mathrm{Phyl}_{2}$ on Figure 5) and the lines at 4.47 and $2.56 \AA$ are hardly detected for layers deeper than $60 \mathrm{~cm}$. The respective intensities of 001 and $h k l$ reflections are due to the particle orientation and are commonly anti-correlated. The fine character of sediments as well as the depletion in quartz and calcite minerals, might enhance the orientation of platelets along the c-axis, and thus favor the $00 l$ reflections including the 001 .

XRD patterns of BETH1402 sediments were particularly fingerprinted by iron oxides (wuestite $\mathrm{FeO}$ and magnetite $\mathrm{Fe}_{3} \mathrm{O}_{4}$ ), iron oxy-hydroxides (goethite $\alpha$-FeOOH) and iron sulfides (pyrite $\mathrm{FeS}_{2}$ ) (bold type labels on the XRD patterns in Figure 5). The general shape of the XRD pattern was strongly modified as soon as the brown siliceous unit from 0 to 11 cm was exceeded. Indeed, peaks of iron minerals, namely goethite (4.18, 2.69 and $2.44 \AA$ ), magnetite $(2.97 \AA$ and $2.53 \AA)$, pyrite $(2.70 \AA)$ and wuestite $(2.15 \AA)$, became more obvious at a depth of $11 \mathrm{~cm}$ (see XRD pattern for the $11-14 \mathrm{~cm}$ layer in Figure 5). The main diffraction peak of pyrite and a secondary diffraction peak for goethite are very close to one another $(2.70 \AA$ and $2.69 \AA$ respectively), thus the evidenced broad peak at $2.69-2.70 \AA$ can be assigned to both iron bearing phases. Nonetheless, goethite and pyrite are certainly both present in the deep sediment layers, due to high iron content and anoxic conditions. Goethite could clearly be detected in the layers $8-11 \mathrm{~cm}$ and $11-14 \mathrm{~cm}$, and the goethite diffraction lines developed in the unit IV (layers $68-131 \mathrm{~cm}$ ). Magnetite and wuestite diffraction lines developed in layer $8-11 \mathrm{~cm}$, with highest intensities in the layers $11-14 \mathrm{~cm}$ and $89-92 \mathrm{~cm}$, and then decreased with depth. This decrease of iron oxide diffraction lines, mainly observed on wuestite diffraction line $(2.15 \AA)$, was combined with an increase of the diffraction line at $7.14 \AA$, as well as an increase of the diffraction lines of the main iron oxy-hydroxide detected in the $11-131 \mathrm{~cm}$ zone via XRD, i.e. goethite at $4.18,2.69$ and $2.44 \AA$.

\subsubsection{Identification of main mineral phases using microscopic tools}


Since XRD is sensitive to major crystalline minerals only, supplementary techniques were used to study the mineralogy of less abundant, poorly crystalline and amorphous phases. Those findings will reveal other Fe-minerals and metal bearing phases. Using multiple microscopic techniques (SEM and TEM), the upper layer $(0-2 \mathrm{~cm})$ was shown to be mainly composed of clay particles. On the basis of EDX spectra, those clays were identified to be predominantly illite, smectite and interlayered illite/smectite, while only few particles of kaolinite could be detected. The different clay minerals were identified on the basis of Si:Al, $\mathrm{Si}: \mathrm{K}$ and $\mathrm{Si}: \mathrm{Mg}$ ratios, and particle morphology. The samples also displayed quartz and iron oxides and oxy-hydroxides associated to clay or carbonate particles (Figure 6). Furthermore, many diatom skeletons could be observed by SEM and by light microscopy in the surface sediment layer $(0-2 \mathrm{~cm})$. This zone exhibited features of natural sediments, originating from soil erosion and biological production in the water column of the Orne watershed. However,

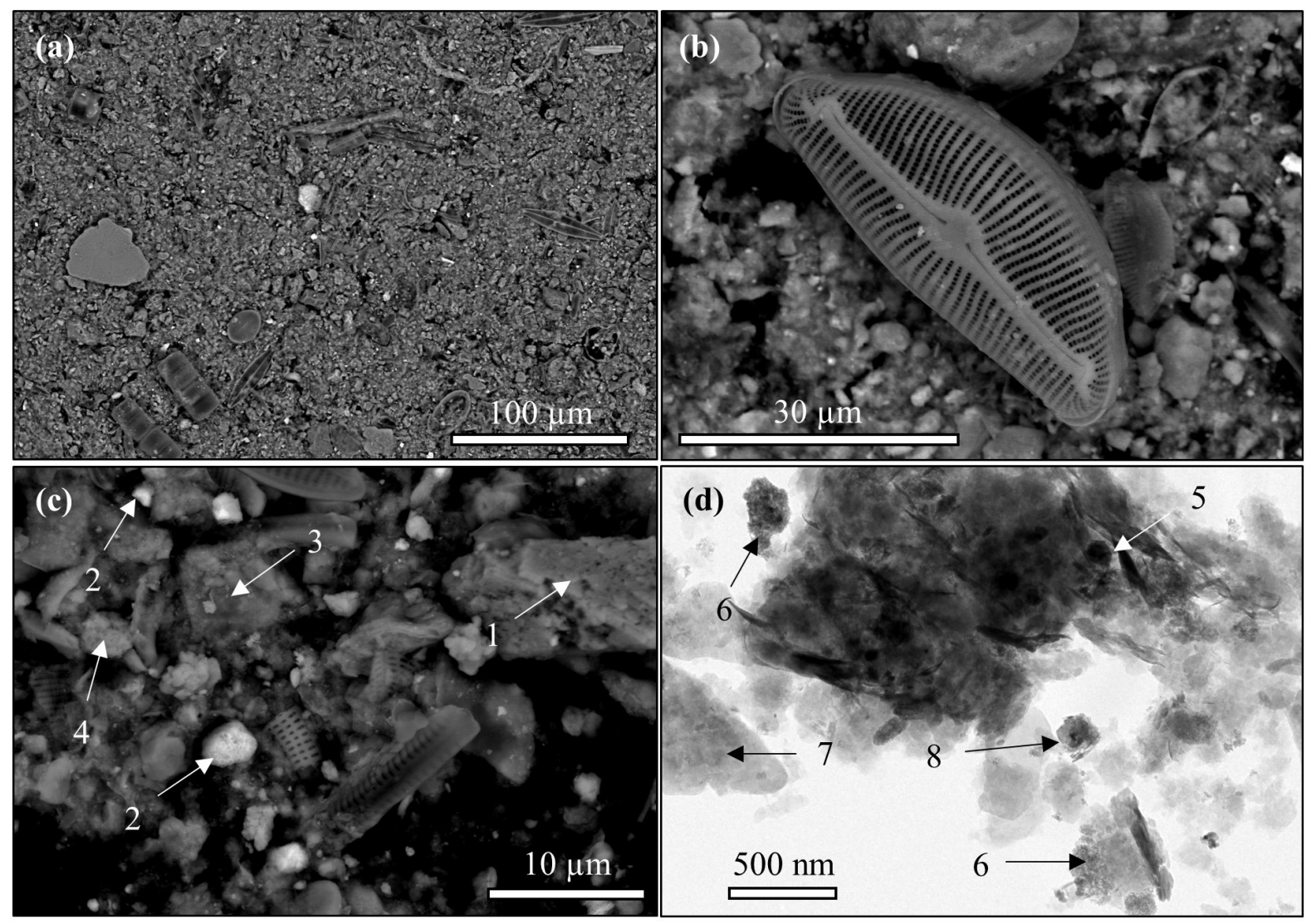

Figure 7: Micro-images for the surface $0-2 \mathrm{~cm}$ layer of BETH1402 core. a, b and c: SEM back-scattered electrons (BSE) micro-images showing a large field of view of the sediment sample, displaying numerous diatom skeletons ( $a$ and $b$ ), and evidencing: 1: calcite, 2: iron oxy-hydroxide, 3: interlayered illite-smectite and 4: calcite. d: TEM micro-image showing: 5: $\mathrm{TiO}_{2}$ particle associated with clay (interlayered illite-smectite), 6: iron oxy-hydroxide, 7: interlayered illite-smectite, and 8: $\mathrm{TiO}_{2}$ and iron oxy-hydroxide. 
although the iron content is not particularly high in those sediments, about $50 \%$ of the particles analyzed via TEM-EDXS contained iron with atomic percentages above $15 \%$.

From 5 to $11 \mathrm{~cm}$, few polymetallic sulfides and Ca-phosphate particles could be detected, suggesting a possible contribution of underlying sediments due to coring, or a contribution of urbanized surface leaching or urban sewer network (El Samrani et al., 2004; Houhou et al., 2009). Furthermore, for units II till IV, EDXS evidenced the prevalence of iron particles in terms of number and content. For layers inferior to $11 \mathrm{~cm}$, clay particles were also present, but strongly less predominant as compared to the first unit. Diatom skeletons were still evidenced in the $11-131 \mathrm{~cm}$ zone, suggesting that the industrial-borne materials were transported by the river and mixed with river-borne particles before settling. The general aspect of particles in the deeper sediments was strongly modified, as it could be expected from the chemical composition (Figure 4 and SM 3). From EDXS analysis, iron seemed to be ubiquitous and detected in more than $90 \%$ of analyzed particles.

\subsubsection{Iron minerals: crystalline, poorly crystalline and amorphous phases}

For layers inferior to $11 \mathrm{~cm}$, distinct iron minerals were observed by microscopic tools (Figure 7: : $a-b$ ).

The iron minerals ranged between 10 and $30 \mu \mathrm{m}$ in diameter and were recognized as ferrospheres. Some of the ferrospheres displayed dendritic magnetite crystals in cracks (Figure 7: : $a-b)$. Iron sulfides were also

evidenced by microscopic observations
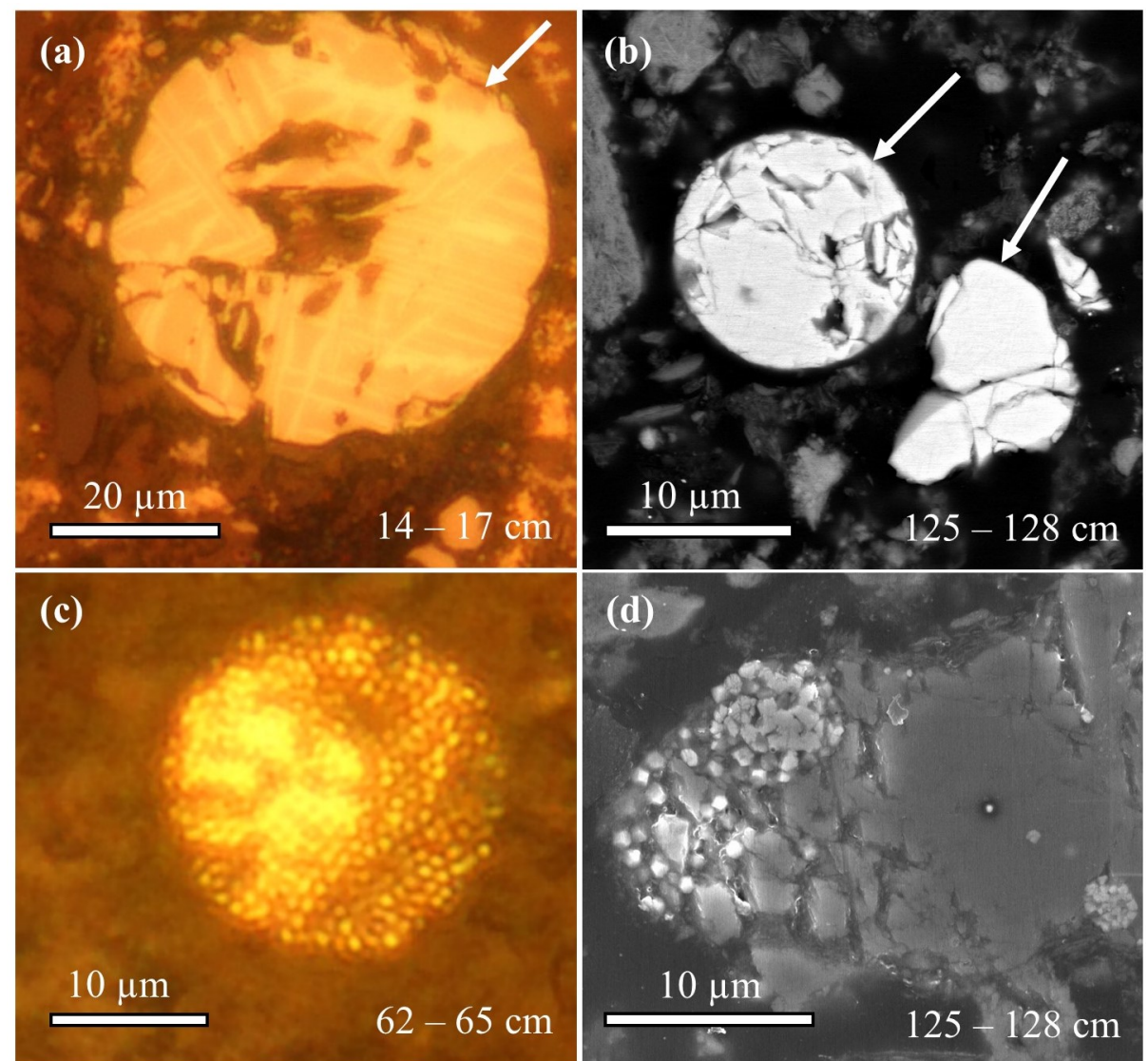

(Figure 7: : c $-\mathrm{d}$ ).

Figure 8: Distinct iron minerals observed by light microscope and SEM. a: light microscope image of layer $14-17 \mathrm{~cm}$ (thin section) showing a ferrosphere with dendritic magnetite in cracks (dark field mode). b: SEM BSE micro-image of layer $125-128 \mathrm{~cm}$ (thin section) showing a ferrosphere and distinct iron oxide fragments. c: Light microscope image (dark field) of layer $62-65 \mathrm{~cm}$ (thin section) showing a framboidal pyrite. d: SEM SE micro-image of layer $125-128 \mathrm{~cm}$ (thin section) showing a framboidal pyrite with octahedral microcrystals. 
Indeed, framboidal pyrites were detected via light microscopy and SEM. Those minerals were detected starting from $5 \mathrm{~cm}$, and were observed till the bottom of the core $(131 \mathrm{~cm})$. Most of the framboidal pyrites were $10 \mu \mathrm{m}$ in diameter. Nonetheless, a few particles as small as $5 \mu \mathrm{m}$, and as large as $20 \mu \mathrm{m}$, in diameter were also seen. Layers $14-26 \mathrm{~cm}$ and $41-65$ $\mathrm{cm}$ contained the highest number of framboidal pyrites (light microscope observations).

At higher spatial resolution, iron nanoparticles could be evidenced in most of the sediment layers by TEM (Figure 8 a). Their cross sections ranged in size from 7 to $39 \mathrm{~nm}$, with an average of $20 \pm 8.2 \mathrm{~nm}$. Even though they were detected starting from $5 \mathrm{~cm}$ depth, those nanoparticles were abundant in all investigated layers below $11 \mathrm{~cm}$ (TEM observations); and the corresponding EDX spectra evidenced an atomic ratio O:Fe close to 2 (Table 1). Similar iron nanoparticles, in shape, size and composition, were also detected in the local iron ore and were identified as goethite $(\mathrm{FeOOH}, \mathrm{O}: \mathrm{Fe}=2)(\mathrm{SM} \mathrm{6})$. The main Fe ore used for steelmaking in Lorraine, also called "Minette" or Loth, was a ferri-arenite, mainly composed of goethite ooids, iron phyllosilicates (chamosite and berthierine), Fe-carbonate or siderite and calcite (Dagallier et al., 2002). SEM observations could unravel the presence of oolitic phases in the sediments, where they appeared as weathered goethite ooids (SM 6 b). Therefore, on the basis of the presence of goethite clearly evidenced by XRD (Figure 5), the identification of goethite nanoparticles with TEM SAED (Figure 8 a), and due to the strong similarity with goethite grains in iron ore "Minette de Lorraine" (SM 6), those nanoparticles were assigned to goethite grains, and were assumed as a fingerprint of iron ore contribution to the sediments. Another predominant phase evidenced by TEM was hairy structured iron rich aluminosilicates (Figure $8 \mathrm{~b}$ ), hereafter named Fe-aluminosilicates. Those phases were mainly detected in the sediments below $11 \mathrm{~cm}$. The main constituents of those phases are $\mathrm{O}$, $\mathrm{Si}, \mathrm{Al}$ and $\mathrm{Fe}$, while the minor ones are $\mathrm{Ca}$ and $\mathrm{Mg}$. Those phases could be recognized by an $\mathrm{Al}: \mathrm{Si}$ atomic ratio of $0.5 \pm 0.2$, and an Fe:Si atomic ratio of $0.9 \pm 0.3$ (Table 1). Those phases were particularly predominant in layers deeper than $60 \mathrm{~cm}$, such as the layer $104-107 \mathrm{~cm}$ (Figure $8 \mathrm{~b}$ ).

In most cases, the hairy Fe-aluminosilicate phases displayed darker rings (Figure $8 \mathrm{c}$ ), strongly suggesting that those Fe-aluminosilicates were resulting from the weathering of circular or spherical entities. Furthermore, the dark ring was shown to include nano-grains of polymetallic $(\mathrm{Zn}, \mathrm{Pb}$ and $\mathrm{Fe})$ sulfides. Such a feature was even more evident for the fine fraction of the deep sediment layers (below $11 \mathrm{~cm}$ ), which was analyzed by XRD and TEMEDXS (Figure 8: $\mathrm{d}-\mathrm{g}$ ). 


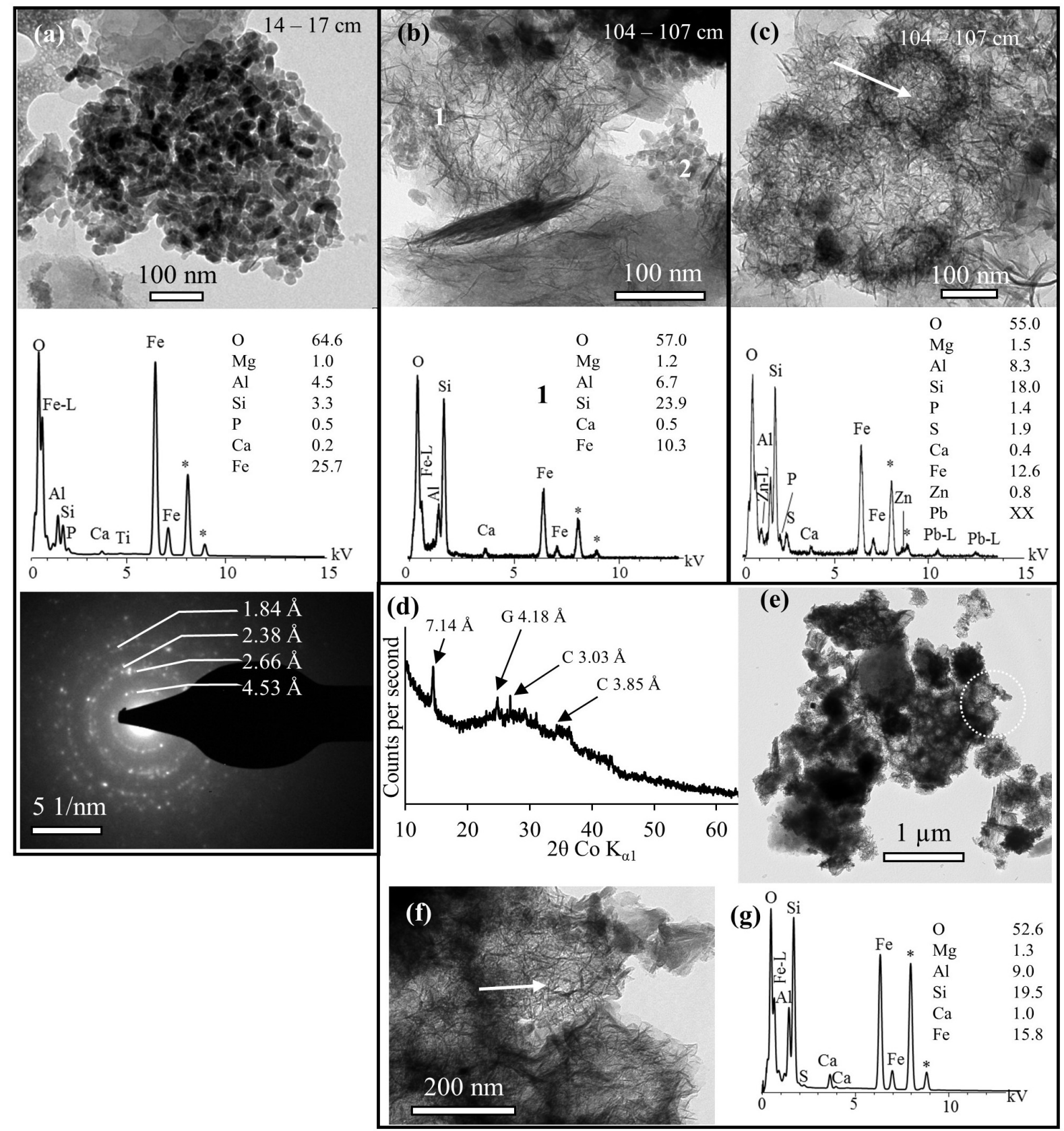

Figure 9: TEM micro-images and corresponding EDX spectra of iron phases.

a: Goethite nanoparticles in layer $14-17 \mathrm{~cm}$ with corresponding EDX spectrum, atomic percentages and SAED pattern. b: Fe-aluminosilicates in layer $104-107 \mathrm{~cm}$ (1) with corresponding EDX spectrum and goethite nanoparticles (2). c: hairy aluminosilicate phases marked by dark rings of Zn-Pb sulfides $(104-107 \mathrm{~cm})$. Due to the presence of $\mathrm{S}, \mathrm{Pb}$ signal is not correctly fitted, therefore the atomic percentage is not given for $\mathrm{Pb} . \mathrm{d}-\mathrm{g}$ : Mineralogy of the selected fine fraction of the metal laden layers of BETH1402 core. d: XRD pattern showing the main crystalline constituent to be a mineral of interplanar distance of $7.14 \AA$. e and f: TEM micro-images showing hairy iron rich aluminosilicate phases and g: corresponding EDX spectrum. The micro-image e shows an aggregate of circular structures; the micro-image f shows a zoomed section of micro-image e (dotted white circle). The hairy phases are associated with rings of fluffy grains, assigned to polymetallic $(\mathrm{Zn}-\mathrm{Pb})$ sulfides. Asterisks on the EDX spectra indicate the emission lines of copper, which are due to the contribution of the TEM grid, a carbon coated copper grid. 
The diffraction reflection corresponding to basal plane $001(7.14 \AA)$ was more evident for the fine fraction, in comparison to the bulk sample, supporting the predominance of phyllosilicates. The same pattern also suggests a light decrease in goethite and other iron oxides in the sample (Figure $8 \mathrm{~d}$ ). TEM observations revealed the predominance of the hairy iron-rich aluminosilicates in the fine fraction of BETH1402 sediments (Figure 8: e - f) as well as the presence of few grains of goethite, polymetallic sulfides and few platelets of clay minerals.

Table 1: Atomic percentages and atomic ratios (average \pm standard deviation) of the elements constituting the goethite nanoparticles and Fe-aluminosilicates

\begin{tabular}{|c|c|c|c|c|c|c|c|}
\hline & \multicolumn{4}{|c|}{ Atomic percentages $(\%)$} & \multicolumn{3}{|c|}{ Atomic ratios } \\
\hline Phase & $\mathrm{O}$ & $\mathrm{Si}$ & $\mathrm{Al}$ & $\mathrm{Fe}$ & $\mathrm{O} / \mathrm{Fe}$ & $\mathrm{Al} / \mathrm{Si}$ & $\mathrm{Fe} / \mathrm{Si}$ \\
\hline $\begin{array}{l}\text { Goethite nanoparticles } \\
\qquad(\mathrm{n}=20)\end{array}$ & $63.3 \pm 2.7$ & - & - & $\begin{array}{c}30.5 \pm \\
2.4\end{array}$ & $\begin{array}{l}2.1 \pm \\
0.2\end{array}$ & - & - \\
\hline $\begin{array}{l}\text { Fe-aluminosilicates } \\
\qquad(\mathrm{n}=44)\end{array}$ & $50.9 \pm 5.8$ & $\begin{array}{c}18.9 \pm \\
3.9\end{array}$ & $\begin{array}{l}9.7 \pm \\
2.0\end{array}$ & $\begin{array}{c}15.1 \pm \\
3.9\end{array}$ & - & $\begin{array}{l}0.5 \pm \\
0.2\end{array}$ & $\begin{array}{r}0.9 \pm \\
0.3\end{array}$ \\
\hline
\end{tabular}

Those hairy aluminosilicates, particularly enriched in iron, were apparently related to the $7.14 \AA$ diffraction line that increased with depth (Figure 5). The hairy phases might be assigned to TO phyllosilicates, constituted of one octahedral and one tetrahedral layer, resulting in basal spacings close to those of TO phyllosilicates. Furthermore, the hairy Fealuminosilicates, or crumpled paper structures, display a three-dimensional aggregate of rings or empty spheres (Figure $8 \mathrm{e}$ ). Again, the EDX spectra showed that the darker rings underlying the circular entities were made of $\mathrm{Zn}-\mathrm{Pb}$ (or $\mathrm{Zn}-\mathrm{Pb}-\mathrm{Fe}$ ) sulfides, and thus strongly suggest that the same processes or a combination of related processes were at the origin of Fe-aluminosilicate and polymetallic sulfides formation within the sediments. 


\section{Discussion}

\subsection{Industrial and natural contributions to the sediment deposits}

From historical data and ${ }^{137} \mathrm{Cs}$ measurements, we assumed that the $120 \mathrm{~cm}$ black materials $(11-131 \mathrm{~cm})$ had settled during the industrial activity period, i.e. from 1960 to 1988. We assumed that the bottom of the deposits was reached at $131 \mathrm{~cm}$, and that no material was eroded during that period. The estimated sedimentation rate is about $4.7 \mathrm{~cm}$ per year, which is more than ten times the sedimentation rate measured in fish ponds located in the Moselle watershed (Bertrand et al., 2012). This estimated sedimentation rate should be put against the activity of the steelmaking site. Indeed, the blast furnaces and the sintering plants were reported to produce 1.3 Mt/yr and $2.4 \mathrm{Mt} / \mathrm{yr}$, respectively (Freyssenet, 1979). The top of the core might represent the materials that had deposited between 1988 and 2014; the estimated sedimentation rate $(0.42 \mathrm{~cm} /$ year $)$ would then be closer to what was measured in Lachaussee and Lansquenet ponds (Bertrand et al., 2012). Considering those numbers, it was difficult to establish a model age for BETH sediments as the main part of the deposit was directly influenced by the steel production, and not by natural sedimentation dynamics. The relatively low thickness of the recent sediment deposit (11 cm only for 26 years) might also be attributed to the erosion of settled materials during the flood event of 1993 (50-year flood, with a maximum flow measured of $318 \mathrm{~m}^{3} / \mathrm{s}$ ). Further investigations on this sediment deposit, including year to year monitoring should bring more detailed explanations about the sedimentation dynamics.

\subsubsection{Natural contributions in Beth sediment deposits}

First of all, unit I $(0-11 \mathrm{~cm})$ of the settled materials displayed lithogenic nature. The detrital character could be evidenced not only by the distinct brown color and relatively higher contents of detrital elements (SM 3), but also by XRD and microscopic tools. Indeed, the predominance of detrital minerals, such as quartz, calcite, illite and smectite, and diatom skeletons (Figure 5 and Figure 6) could be clearly evidenced. The contents of REEs evidence the geochemical background (Hu et al., 2006; Wen et al., 2014). Nonetheless, since the deposited materials were highly influenced by steelmaking wastes in our case, only the light lanthanides $\mathrm{La}, \mathrm{Ce}, \mathrm{Nd}$ and $\mathrm{Pr}$ were used to fingerprint the detrital contributions. Indeed, the contents of light REEs were anticorrelated to $\mathrm{Fe}, \mathrm{Zn}$ and $\mathrm{Pb}$ ( $\mathrm{SM}$ 4). In addition, the high $\mathrm{Si}$ and $\mathrm{Ca}$ contents in the first unit were assigned to the erosion of argillaceous surface layers of the Woëvre region (Figure $1 \mathrm{a}$ ), and the detrital crystalline minerals (quartz and calcite) were 
shown to be commonly transported in the Moselle River and its tributaries (Le Meur et al., 2016; Montargès-Pelletier et al., 2007). In the deeper sediments (inferior to $11 \mathrm{~cm}$ ), the contribution of detrital elements, minerals and diatom skeletons could still be evidenced, but significantly less than the first unit; therefore, indicating the combined contributions of natural SPM and steelmaking wastes in the deposited materials.

\subsubsection{Industrial contributions to the sediments, ferrous and non-ferrous materials}

The origin of the sediment particles between 11 and $131 \mathrm{~cm}$ depth can be undoubtedly related to former steelmaking activities. The investigation of sediment mineralogy revealed, or at least suggested, different and distinct units in the sediment profile, certainly related to diverse periods of activity in the vicinity of the Beth dam. The main iron phases detected in the layers below $11 \mathrm{~cm}$ were goethite, magnetite, wuestite, pyrite, Fe rich aluminosilicates and (poly)metallic sulfides (XRD, SEM and TEM). The mineral phases evidenced in the sediments below $11 \mathrm{~cm}$ resulted from different outputs of the steelmaking processes as well as likely weathering processes within the sediment profile. Different sources of iron were present on the site, such as iron ore, cast iron, iron scraps, sludges from the wet cleaning of furnace smokes, and fly ashes from the sintering plant, blast furnaces or converters (see SM 1 for machineries that were installed upstream of the dam).

At elevated temperatures inside the blast furnace $\left(1200\right.$ to $\left.1600^{\circ} \mathrm{C}\right)$, some elements are volatilized and are partially evacuated with furnace smoke. This is the case for $\mathrm{Zn}$ and $\mathrm{Pb}$ (Trinkel et al., 2016, 2015). In Lorraine steel facilities, the furnace smokes were cleaned through a wet procedure, resulting in sludge with particularly high contents of metallic elements (such as $\mathrm{Pb}$ and $\mathrm{Zn}$ ), which partly explains the high contents of those elements in the $11-131 \mathrm{~cm}$ layers (Figure 4). Furthermore, sludge cannot be re-used in the blast furnace if enriched with metals, such as $\mathrm{Pb}$ and $\mathrm{Zn}$ (few hundred $\mathrm{mg} / \mathrm{kg}$ to a few \%) (Das et al., 2007, 2002; Kretzschmar et al., 2012); therefore, it is piled or dumped in settling ponds (Mansfeldt and Dohrmann, 2004). In the settling ponds, supplementary reactions occur due to the presence of water and atmospheric gases, which result in mineralogical transformations, mainly hydration and carbonatation. Another industrial contribution to the sediments can be expected from slagheap exploitation. Besides the production of metallic iron, the by-product slag is formed, which is rich in $\mathrm{Si}, \mathrm{Ca}, \mathrm{Al}$ and $\mathrm{Mg}$ (ore constituents), and forms glass-like phases. As the molten slag is channeled out of the blast furnace, it is rapidly quenched with 
water, which results in the formation of granular material, which were stored as slagheaps near the Orne River (Figure $1 \mathrm{~b}$ ). Only few of those granulated materials could be seen as spheres of $\mathrm{Si}, \mathrm{Al}$ and $\mathrm{Mg}$ (SM 7). Those glass-like phases can display different shapes and sizes, depending on the cooling speed, and can from (sub)-micrometric to meter size blocks (Sobanska et al., 2016; Vassilev and Vassileva, 1996).

Vanadium had retained our attention because it was one of the trace elements that increased with depth, particularly in the last two units (units III and IV in Figure 4 b), while other trace metals fluctuated, such as $\mathrm{Zn}$ and $\mathrm{Pb}$, or were quite steady, such as Ni and Co (SM 3). Vanadium is known to be relatively concentrated in fossil fuels, with values up to 1000 $\mathrm{mg} / \mathrm{kg}$ in petroleum and $100 \mathrm{mg} / \mathrm{kg}$ in coal (Groen and Craig, 1994; Xu et al., 2004). Upon combustion, and particulary coke production from coal, high contents of $\mathrm{V}$ (up to $0.1 \%$ ) are majorly associated to the emitted ashes, since V is not volatile (Helble and Sarofim, 1993; López-Antón et al., 2011). Usually, V is used as a tracer of oil in petroleum basins. In the context of the Orne River, the steelmaking industry produced coke in facilities located in Homécourt and Moyeuvre-Grande (Figure $1 \mathrm{~b}$ ). The presence of such high V contents in the sediments could be assigned to the coke production, while the decrease of $\mathrm{V}$ contents from the bottom up might be due to the progressive decline of coke production in the 1980's, which was followed by the dismantling of the Homécourt facilities, while steel production at Moyeuvre-Grande was still active until 1988.

The iron ore demonstrated to be one of the sources of iron in those sediments since the nanometric sized grains of goethite are particularly similar to those found in the Minette iron ore (Figure 8 a and SM 6). Furthermore, few parts of oolites were evidenced with SEM (SM $6 \mathrm{~b}$ ). The fine grain size distribution of the settled sediments strongly suggests that part of the materials that had settled in the riverbed were mainly originating from blast furnace smokes, with or without wet cleaning, and enriched with micro-particles and nano-particles, such as ferrospheres. Such ferrospheres are very common in coal combustion, fly ash, unburnt fuel from ferrous metallurgy and by-products from blast furnaces (Huang et al., 2015; Moskalyk and Alfantazi, 2003), and were shown to have dendritic magnetite crystals in their cracks (Valentim et al., 2016; Zhao et al., 2006). Moreover, quenching of molten iron results in the formation of ferrospheres (Sokol et al., 2002). Indeed, ferrospheres are also common in metallurgical wastes and were already evidenced in the suspended matter and sediments of a neighboring steel river (Montargès-Pelletier et al., 2014). Additionally, and from a mineralogical point of view, crystalline mineral phases, such as wuestite and magnetite, are 
formed during the release of furnace smokes and partly constitute the fly ashes (Sharonova et al., 2013; Valentim et al., 2016).

\subsection{Evolution of the iron minerals}

The formation of crystalline framboidal pyrites in Fe and S rich sediments commonly occurs in anoxic conditions (Wilkin and Barnes, 1997), and was expected in our case (Figure 7: $\mathrm{c}-\mathrm{d})$. However, since iron was majorly detected as distinct phases and highly linked to steelmaking activities, the variation of iron mineralogy could be considered as a fingerprint of the industrial activity in the vicinity of the dam. On a study concerning a neighboring steelmaking facility along the Fensch River, mineralogy of sediments and suspended particulate matter had revealed the occurrence of numerous spherical iron oxides.Those phases, more or less weathered, covered a wide size range and were directly related to the steelmaking activity (Montargès-Pelletier et al., 2014, 2007). SPM and sediments were collected while the steel industry was still active. Ferrospheres of various sizes could be observed in sediments and SPM of the Fensch river and were spatially associated to Fealuminosilicates (Montargès-Pelletier et al., 2014). Moreover, spherical entities were also evidenced in sludge settling ponds by Huot et al., (2014), but their chemical composition was close to that of slag, i.e. mainly constituted of Al and Si. Indeed, those light elements originate from the pristine ore after their separation from iron in the blast furnace or in the sintering plant. Weathering of those glassy slag particles or iron oxide spheres resulted into the formation of the hairy aluminosilicates identified as crumpled paper or hairy structures, referred to as "allophane-like" by Huot et al., (2014). The chemical composition of the hairy aluminosilicates depends on the type of industry ( $\mathrm{Zn}$ or Fe metallurgy for example), raw materials used, sludge by-products (e.g. Kretzschmar et al., 2012; Mansfeldt and Dohrmann, 2004). In addition, the composition of hairy aluminosilicates might be influenced by the weathering processes. In the BETH1402 sediments, only few iron oxide spheres (ferrospheres) were detected at the scale of the light microscope (i.e. from few microns to several tens of microns) (Figure 7: $a-b$ ), thus suggesting the contribution of fly ashes or sludge in the sediments. Those spheres were not evidenced at the sub-micrometric scale (TEM), as it was the case for Fensch sediments and SPM (Montargès-Pelletier et al., 2014). As a result, only the ghost of their spherical shape is suggested by the spatial organization of newly formed Fe-aluminosilicates, (Figure 8: $\mathrm{c}$ and e). The high Fe content of the hairy phase and the spherical voids that appear to structure their aggregates strongly call for a relationship between those Fe-phases and expected ferrospheres. 
The processes resulting in the formation of Fe-aluminosilicates were not identified with precision, and due to the various origins of iron in the sediments, several hypotheses need to be debated. Indeed, the presence of such Fe-aluminosilicates could be assigned to iron ore contribution, since the Minette contains iron-rich phyllosilicates, such as chamosite and berthierine (Dagallier et al., 2002). In addition, crumpled paper-like phases, similar to Fealuminosilicates, were shown to be the bio-reduction product of Minette iron ore minerals (Maitte et al., 2015). Although the hairy aluminosilicates were microscopically similar (between this study and Maitte et al., (2015)), the crumpled paper-like phases showed lower Fe contents in the case of BETH1402 sediments (Maitte, personal communication). Similar Fe-aluminosilicates were also identified in the case of controlled experiments, where the interaction between metal iron and purified clay was studied (Rivard et al., 2013); the composition of the resulted phase was close to berthierine minerals, with typical basal spacing at $7.13 \AA$. The starting material is likely to be the ferrospheres (evidenced by light microscopy and SEM), which is mainly iron made, and is constituted of a mixture of wuestite and magnetite, as suggested by the Fe:O ratios. However, the possible sources of the light elements, Si and Al, are more than a few. The presence of slagheaps, and thus the possible introduction of silico-calcic spheres in the sludge might be one possibility; but since Si and Al drastically decreased below $11 \mathrm{~cm}$ depth (Figure 4 a and SM 3), the contribution of slag to the sediments should be minor. The contribution of clay minerals, naturally occurring as suspended particles in the Orne waters, detrital quartz and diatom skeletons can also be retained as supplementary explanations. Indeed, diatom frustules are constituted of amorphous silica, which is supposed to be more reactive than phyllosilicates or quartz. In an attempt to characterize the weathering products of industrial sludge on one hand, and to decipher the contributions of natural and iron ore minerals that constitute the sediments and SPM of Orne River on the other, we reported the atomic proportions of $\mathrm{Fe}, \mathrm{Al}$ and $\mathrm{Si}$ (that were determined by EDXS) in a ternary diagram (Figure 9). On the basis of this Fe-Al-Si diagram on Orne River sediments (hairy Fe-aluminosilicates), Fensch River SPM (hairy Fealuminosilicates), iron ore particles (Fe-clays), and natural clays evidenced majorly in the top layers of BETH1402, there is a clear distinction between the newly formed $\mathrm{Fe}$ aluminosilicates and the Fe-clays constituting the iron ore. Iron content is higher in the Fealuminosilicates for sediments and SPM collected from the steel rivers (Orne and Fensch Rivers, respectively). In addition, there is an overlapping of newly formed $\mathrm{Fe}$ aluminosilicates and Fe-clays from iron ore, which is certainly due to the presence of iron ore (Dagallier et al., 2002) in the sediments. However, the ternary diagram also demonstrates the 
distinction between the $\mathrm{Fe}$ aluminosilicates and naturally occurring clays in the sediments, which are mainly interlayered clays (illite/smectite) with lower iron contents. Si:Al atomic ratios were calculated for the same series of EDXS data, and showed only small variations, i.e., $\mathrm{Si}$ Al was $2.0 \pm$ 0.5 for Fe-aluminosilicates, 1.8 \pm 0.5 for autochthonous clays and $1.65 \pm 0.3$ for Fe-clays of the iron ore. From the few EDX spectra acquired on silicoaluminous slag particles (SM 7), $\mathrm{Si}: \mathrm{Al}$ ratio is noticeably higher than 2.0, and reached as much as 3.2 for one particle. Although the number of micro-

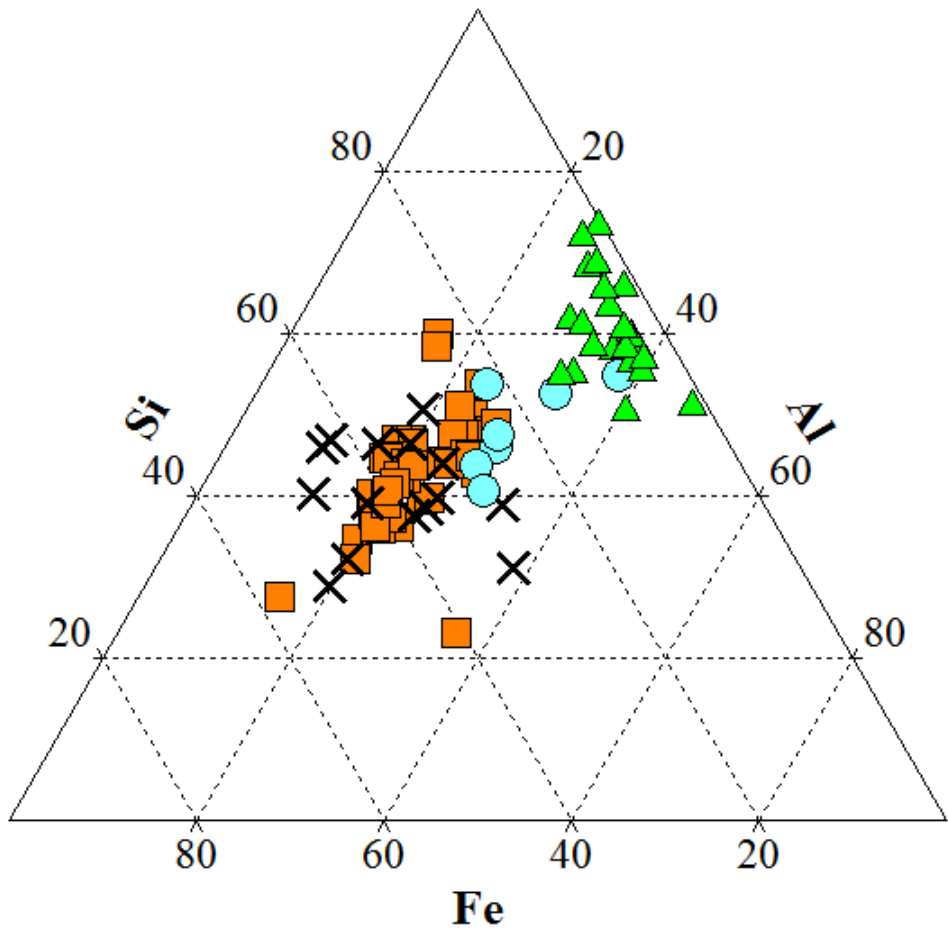

Figure 10: Ternary diagram showing the atomic percentages of $\mathrm{Fe}, \mathrm{Al}$ and $\mathrm{Si}$ measured by EDXS on $\mathrm{Fe}$-aluminosilicates particles from BETH1402 sediments $(\square, \mathrm{n}=44)$ and compared to similar hairy structures observed in the SPM from a neighboring steel river, the Fensch River, (, $\mathrm{n}=15$ ) (Montargès-Pelletier et al., 2014), Fe-clays from the iron ore, Minette de Lorraine $(O, n=7)$, and the clays evidenced in the top layers of the sediment core $(\triangle$, $\mathrm{n}=24)$.

analyses is not sufficient to certainly evidence the contribution of slag particles to the formation of the Fe-aluminosilicates, we propose that several sources of Si and Al, including slag particles, were involved in the formation of these hairy phases. The weathering of the ferrospheres might have begun on land, and continued in the sediments, after a mixing step with natural suspended matter in the water column. Finally, Figure 10 shows a schematic summary of the formation of Fe-aluminosilicates. At this stage, it is not really possible to identify the chemical mechanism(s) and the bacterial metabolism(s) involved in such mineralogical transformation(s), but we can still imagine some hypothetical processes on the basis of what is known about metal corrosion (e.g. Liu et al., 2015). 


\section{Conclusion}

The vertical profile of contaminated river sediments in a former steelmaking area was investigated using grain sizes, chemical composition and mineralogical examination at a bulk and sub-micrometric scale. The investigation of sediment mineralogy brought new interpretations on the chemical profiles with depth. The sedimentary materials were obviously characterized by iron rich minerals emitted from steelmaking facilities in the area upstream of the dam. The detected iron rich phases were goethite,
Ferrospheres

( $\mathrm{FeO}$ and $\mathrm{Fe}_{3} \mathrm{O}_{4}$ )

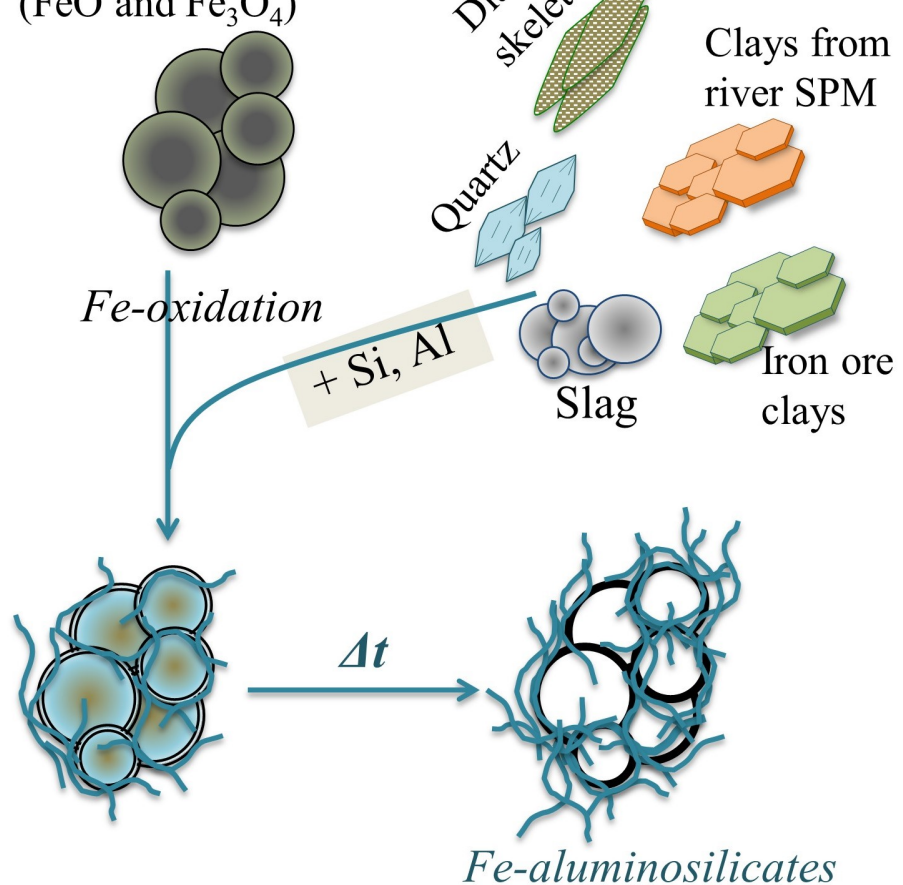

Figure 11: Schematic representation on the hypothesis of hairy Fe-aluminosilicate formation. Iron in the ferrospheres is oxidized and reacts with $\mathrm{Al}$ and $\mathrm{Si}$ from different sources (clays, diatom skeletons and quartz naturally occurring in the Orne River, Fe rich clays from the iron ore and slag particles) to form hairy Fealuminosilicates with time.

magnetite, wuestite, pyrite and newly formed Fe-aluminosilicates, the former fingerprinting the iron ore and the four last minerals from the steelmaking sludge, more or less aged and weathered. Additional investigations on slagheap samples will compare the weathering processes on the land surface and should unravel the specificity of weathering processes within the sediments. In this study, Fe-aluminosilicate was shown to be the predominant phase in the fine fraction of the contaminated sediments. Fe-aluminosilicates could also be used as markers in sediments and suspended particulate matter that have been influenced by steelmaking wastes. Moreover, the specific tridimensional organization of $\mathrm{Fe}$ aluminosilicates, having polymetallic sulfides as crowns, further support the idea that those phases can be used as tracers for sediment remobilization in riverine systems. Nonetheless, the fate of the formed polymetallic sulfides remains unknown, but it is thought that sulfide dissolution and metal $(\mathrm{Fe}, \mathrm{Zn}$ and $\mathrm{Pb})$ release is a possible scenario upon sediment remobilization, which might be caused by floods, or dam modification or removal (Simpson et al., 2000). Studies concerning $\mathrm{Zn}, \mathrm{Pb}$ and $\mathrm{Ni}$ isotopes are underway on Orne suspended 
matter and vertical layers of BETH1402 sediments to reveal the different sources of the anthropogenic materials that had settled upstream the dam.

\section{Conflict of interest}

The authors declare that there is no conflict of interest.

\section{Acknowledgements}

The authors would like to thank Long-Term Ecosystem Research (LTER) France, Agence Nationale de la Recherche (ANR) project number ANR-14-CE01-0019, RésEAU LorLux and Region Lorraine through the research network of Zone Atelier Moselle (ZAM) for partially funding the work. We would also like to thank Ms. Marie-Françoise Gerard and Ms. Manel Khedri who worked on several aspects of the sediments of the Orne, Mr. Marc Desmet (GEHCO, University of Tours) for providing the aquaraft that was used for the coring, Mr. Patrick Billard (LIEC, Lorraine University) for helping during the sampling, Mr. Jean-Marie Fischbach and Mr. Frederic Diot (GeoRessources, Lorraine University) for the access to the XRF Niton gun, Ms. Lise Salsi (GeoRessources, Lorraine University) for SEM access, Ms. Sylvie Migot and Mr. Jaafar Ghanbaja (IJL, Lorraine University) for TEM access, Ms. Irene Lefèvre (LSCE) for valuable discussion regarding sediment dating, and the city of Moyeuvre for granting us access to the sampling site. We also thank ERASMUS-ELEMENT (This project has been funded with support of the European Commission. This publication (communication) reflects the view only of the author, and the Commission cannot be held responsible for any use which may be made of the information contained therein). Finally, we would also like to thank the anonymous reviewer(s) for their critical review and constructive comments. 


\section{References}

Appleby, P.G., Oldfield, F., 1992. Applications of lead-210 to sedimentation studies, in: Harmon, M. (Ed.), Uranium-Series Disequilibrium: Applications to Earth, Marine, and Environmental Sciences. Clarendon Press, OXford, p. 910.

Ayrault, S., Roy-Barman, M., Le Cloarec, M.F., Priadi, C.R., Bonté, P., Göpel, C., 2012. Lead contamination of the Seine River, France: Geochemical implications of a historical perspective. Chemosphere 87, 902-910. doi:10.1016/j.chemosphere.2012.01.043

Bertrand, O., Mansuy-Huault, L., Montargès-Pelletier, E., Losson, B., Argant, J., Ruffaldi, P., Etienne, D., Garnier, E., Dezileau, L., Faure, P., Michels, R., 2012. Molecular evidence for recent land use change from a swampy environment to a pond (Lorraine, France). Org. Geochem. 50, 1-10. doi:10.1016/j.orggeochem.2012.06.004

Cappuyns, V., Swennen, R., Devivier, A., 2006. Dredged river sediments: Potential chemical time bombs? A case study. Water, Air, Soil Pollut. 171, 49-66. doi:10.1007/s11270005-9012-y

Carignan, J., Hild, P., Mevelle, G., Morel, J.-L., Yeghicheyan, D., 2001. Routine analyses of trace elements in geological samples using flow injection and low pressure on-line liquid chromatography coupled to ICP-MS: A study of geochemical reference materials BR, DR-N, UB-N, AN-G and GH. Geostand. Geoanalytical Res. 25, 187-198. doi:10.1111/j.1751-908X.2001.tb00595.x

Dagallier, G., Grgic, D., Homand, F., 2002. Caractérisation minéralogique et microtexturale $\mathrm{du}$ vieillissement anthropique du minerai de fer lorrain. Comptes Rendus Geosci. 334, 455-462. doi:10.1016/S1631-0713(02)01783-2

Das, B., Prakash, S., Reddy, P.S.R., Biswal, S.K., Mohapatra, B.K., Misra, V.N., 2002. Effective utilization of blast furnace flue dust of integrated steel plants. Eur. J. Miner. Process. Environ. Prot. 2, 61-68.

Das, B., Prakash, S., Reddy, P.S.R., Misra, V.N., 2007. An overview of utilization of slag and sludge from steel industries. Resour. Conserv. Recycl. 50, 40-57. doi:10.1016/j.resconrec.2006.05.008

Dewit, J., Swennen, R., Manceau, A., Van Damme, A., Degryse, F., Smolders, E., Sarret, G., Dewit, J., Swennen, R., Manceau, A., 2010. Zinc speciation in mining and smelter contaminated overbank sediments by EXAFS spectroscopy. Geochim. Cosmochim. Acta 74, 3707-3720. doi:10.1016/j.gca.2010.03.032

Dhivert, E., Grosbois, C., Courtin-Nomade, A., Bourrain, X., Desmet, M., 2016. Dynamics of metallic contaminants at a basin scale - Spatial and temporal reconstruction from four sediment cores (Loire fluvial system, France). Sci. Total Environ. 541, 1504-1515. doi:10.1016/j.scitotenv.2015.09.146

Droppo, I.G., Liss, S.N., Williams, D., Nelson, T., Jaskot, C., Trapp, B., 2009. Dynamic existence of waterborne pathogens within river sediment compartments. Implications for water quality regulatory affairs. Environ. Sci. Technol. 43, 1737-1743. doi:10.1021/es802321w

El Samrani, A.G., Lartiges, B.., Ghanbaja, J., Yvon, J., Kohler, A., 2004. Trace element carriers in combined sewer during dry and wet weather: an electron microscope investigation. Water Res. 38, 2063-2076. doi:10.1016/j.watres.2004.01.029

Fernandes, G.W., Goulart, F.F., Ranieri, B.D., Coelho, M.S., Dales, K., Boesche, N., Bustamante, M., Carvalho, F.A., Carvalho, D.C., Dirzo, R., Fernandes, S., Galetti, P.M., Millan, V.E.G., Mielke, C., Ramirez, J.L., Neves, A., Rogass, C., Ribeiro, S.P., Scariot, A., Soares-Filho, B., 2016. Deep into the mud: ecological and socio-economic impacts of the dam breach in Mariana, Brazil. Nat. Conserv. 14, 35-45. 
doi:10.1016/j.ncon.2016.10.003

Ferrand, E., Eyrolle, F., Radakovitch, O., Provansal, M., Dufour, S., Vella, C., Raccasi, G., Gurriaran, R., 2012. Historical levels of heavy metals and artificial radionuclides reconstructed from overbank sediment records in lower Rhône River (South-East France). Geochim. Cosmochim. Acta 82, 163-182. doi:10.1016/j.gca.2011.11.023

Freyssenet, M., 1979. La sidérurgie française: 1945 - 1979, l'histoire d'une faillite, les solutions qui s'affrontent. Savilli, Paris.

Fryirs, K.A., Brierley, G.J., 2012. Sediment movement and deposition in river systems: An approach to reading the landscape, in: Geomorphic Analysis of River Systems. John Wiley \& Sons, Ltd, Chichester, UK, pp. 81-115. doi:10.1002/9781118305454.ch6

Garcier, R.J., 2007. Rivers we can't bring ourselves to clean - historical insights into the pollution of the Moselle River (France), 1850-2000. Hydrol. Earth Syst. Sci. Discuss. 11, $1731-1745$.

Grabowski, R.C., Droppo, I.G., Wharton, G., 2011. Erodibility of cohesive sediment: The importance of sediment properties. Earth-Science Rev. 105, 101-120. doi:10.1016/j.earscirev.2011.01.008

Groen, J.C., Craig, J.R., 1994. The inorganic geochemistry of coal, petroleum, and their gasification/combustion products. Fuel Process. Technol. 40, 15-48. doi:10.1016/03783820(94)90033-7

Heise, S., Förstner, U., 2007. Risk assessment of contaminated sediments in river basinstheoretical considerations and pragmatic approach. J. Environ. Monit. 9, 943-952. doi:10.1039/b704071g

Helble, J.J., Sarofim, A.F., 1993. Trace element behavior during coal combustion. Am. Chem. Soc. Div. fuel Chem. Repr. Chem. Soc. Div. FUEL Chem. 38, 257-264.

Houhou, J., Lartiges, B.S., Hofmann, A., Frappier, G., Ghanbaja, J., Temgoua, A., 2009. Phosphate dynamics in an urban sewer: A case study of Nancy, France. Water Res. 43, 1088-1100. doi:10.1016/j.watres.2008.11.052

Hu, Z., Sparovek, G., Haneklaus, S., Schnug, E., 2006. Rare earth elements, in: Lal, R. (Ed.), Encyclopedia of Soil Science. CRC Press, pp. 1437-1441. doi:10.1081/E-ESS120015983

Huang, J.-H., Huang, F., Evans, L., Glasauer, S., 2015. Vanadium: Global (bio)geochemistry. Chem. Geol. 417, 68-89. doi:10.1016/j.chemgeo.2015.09.019

Hudson-Edwards, K.A., Macklin, M.G., Brewer, P.A., Dennis, I.A., 2008. Assessment of metal mining-contaminated river sediments in England and Wales. Environment Agency, Bristol, UK.

Huot, H., Simonnot, M.-O., Marion, P., Yvon, J., Donato, P. De, Morel, J.-L., 2013. Characteristics and potential pedogenetic processes of a Technosol developing on iron industry deposits. J. Soils Sediments 13, 555-568. doi:10.1007/s11368-012-0513-1

Huot, H., Simonnot, M.O., Watteau, F., Marion, P., Yvon, J., De Donato, P., Morel, J.-L., 2014. Early transformation and transfer processes in a Technosol developing on iron industry deposits. Eur. J. Soil Sci. 65, 470-484. doi:10.1111/ejss.12106

Kretzschmar, R., Mansfeldt, T., Mandaliev, P.N., Barmettler, K., Marcus, M.A., Voegelin, A., 2012. Speciation of $\mathrm{Zn}$ in blast furnace sludge from former sedimentation ponds using synchrotron X-ray diffraction, fluorescence, and absorption spectroscopy. Environ. Sci. Technol. 46, 12381-12390. doi:10.1021/es302981v

Le Cloarec, M.-F., Bonte, P.H., Lestel, L., Lefèvre, I., Ayrault, S., 2011. Sedimentary record of metal contamination in the Seine River during the last century. Phys. Chem. Earth, Parts A/B/C 36, 515-529. doi:10.1016/j.pce.2009.02.003

Le Meur, M., Montargès-Pelletier, E., Bauer, A., Gley, R., Migot, S., Barres, O., Delus, C., Villiéras, F., 2016. Characterization of suspended particulate matter in the Moselle River 
(Lorraine, France): evolution along the course of the river and in different hydrologic regimes. J. Soils Sediments 16, 1625-1642. doi:10.1007/s11368-015-1335-8

Lepage, H., Evrard, O., Onda, Y., Lefèvre, I., Laceby, J.P., Ayrault, S., 2015. Depth distribution of cesium-137 in paddy fields across the Fukushima pollution plume in 2013. J. Environ. Radioact. 147, 157-164. doi:10.1016/j.jenvrad.2015.05.003

Lesven, L., Lourino-Cabana, B., Billon, G., Recourt, P., Ouddane, B., Mikkelsen, O., Boughriet, A., 2010. On metal diagenesis in contaminated sediments of the Deûle river (northern France). Appl. Geochemistry 25, 1361-1373. doi:10.1016/j.apgeochem.2010.06.007

Liu, H., Fu, C., Gu, T., Zhang, G., Lv, Y., Wang, H., Liu, H., 2015. Corrosion behavior of carbon steel in the presence of sulfate reducing bacteria and iron oxidizing bacteria cultured in oilfield produced water. Corros. Sci. 100, 484-495. doi:10.1016/j.corsci.2015.08.023

López-Antón, M.A., Díaz-Somoano, M., Ochoa-González, R., Martínez-Tarazona, M.R., 2011. Distribution of trace elements from a coal burned in two different spanish power stations. Ind. Eng. Chem. Res. 50, 12208-12216. doi:10.1021/ie2018542

Lourino-Cabana, B., Lesven, L., Billon, G., Proix, N., Recourt, P., Ouddane, B., Fischer, J.C., Boughriet, A., 2010. Impacts of metal contamination in calcareous waters of Deûle River (France): Water quality and thermodynamic studies on metallic mobility. Water. Air. Soil Pollut. 206, 187-201. doi:10.1007/s11270-009-0095-8

Macklin, M.G., Hudson-Edwards, K.A., Dawson, E.J., 1997. The significance of pollution from historic metal mining in the Pennine orefields on river sediment contaminant fluxes to the North Sea. Sci. Total Environ. 194-195, 391-397. doi:10.1016/S00489697(96)05378-8

Maclin, E., Sicchio, M., 1999. Dam removal success stories, restoring rivers through selective removal of dams that don't make sense.

Maitte, B., Jorand, F.P.A., Grgic, D., Abdelmoula, M., Carteret, C., 2015. Remineralization of ferrous carbonate from bioreduction of natural goethite in the Lorraine iron ore (Minette) by Shewanella putrefaciens. Chem. Geol. 412, 48-58. doi:10.1016/j.chemgeo.2015.07.024

Mansfeldt, T., Dohrmann, R., 2004. Chemical and mineralogical characterization of blastfurnace sludge from an abandoned landfill. Environ. Sci. Technol. 38, 5977-5984. doi:10.1021/es040002+

Montargès-Pelletier, E., Duriez, C., Ghanbaja, J., Jeanneau, L., Falkenberg, G., Michot, L.J., 2014. Microscale investigations of the fate of heavy metals associated to iron-bearing particles in a highly polluted stream. Environ. Sci. Pollut. Res. 21, 2744-2760. doi:10.1007/s11356-013-2192-x

Montargès-Pelletier, E., Jeanneau, L., Faure, P., Bihannic, I., Barres, O., Lartiges, B.S., 2007. The junction of Fensch and Moselle rivers, France; mineralogy and composition of river materials. Environ. Geol. 53, 85-102. doi:10.1007/s00254-006-0621-6

Moskalyk, R.R., Alfantazi, A.M., 2003. Processing of vanadium: a review. Miner. Eng. 16, 793-805. doi:10.1016/S0892-6875(03)00213-9

Picon, M., 2014. Autour de l'Orne industrieuse : paysages industriels hérités. Université de Lorraine, 34 cours Léopold, 54000 Nancy.

Radakovitch, O., Charmasson, S., Arnaud, M., Bouisset, P., 1999. ${ }^{210} \mathrm{~Pb}$ and Caesium accumulation in the Rhône delta sediments. Estuar. Coast. Shelf Sci. 48, 77-92. doi:10.1006/ecss.1998.0405

Rivard, C., Montargès-Pelletier, E., Vantelon, D., Pelletier, M., Karunakaran, C., Michot, L.J., Villiéras, F., Michau, N., 2013. Combination of multi-scale and multi-edge X-ray spectroscopy for investigating the products obtained from the interaction between 
kaolinite and metallic iron in anoxic conditions at $90{ }^{\circ} \mathrm{C}$. Phys. Chem. Miner. 40, 115132. doi:10.1007/s00269-012-0552-6

Robbins, J.A., Edgington, D.N., 1975. Determination of recent sedimentation rates in Lake Michigan using Pb-210 and Cs-137. Geochim. Cosmochim. Acta 39, 285-304. doi:10.1016/0016-7037(75)90198-2

Roberts, D.R., Scheinost, A.C., Sparks, D.L., 2002. Zinc speciation in a smelter-contaminated soil profile using bulk and microspectroscopic techniques. Environ. Sci. Technol. 36, 1742-1750. doi:10.1021/es015516c

Sawhney, B.L., 1972. Selective sorption and fixation of cations by clay minerals: a review. Clays Clay Miner. 20, 1972.

Sharonova, O.M., Anshits, N.N., Anshits, A.G., 2013. Composition and morphology of narrowly sized ferrospheres isolated from various types of fly ash. Inorg. Mater. 49, 586-594. doi:10.1134/S0020168513060113

Simpson, S.L., Apte, S.C., Batley, G.E., 2000. Effect of short-term resuspension events on the oxidation of cadmium, lead, and zinc sulfide phases in anoxic estuarine sediments. Environ. Sci. Technol. 34, 4533-4537. doi:10.1021/es991440x

Simpson, S.L., Apte, S.C., Batley, G.E., 1998. Effect of short-term resuspension events on trace metal speciation in polluted anoxic sediments. Environ. Sci. Technol. 32, 620-625. doi:10.1021/es970568g

Sobanska, S., Deneele, D., Barbillat, J., Ledésert, B., 2016. Natural weathering of slags from primary $\mathrm{Pb}-\mathrm{Zn}$ smelting as evidenced by Raman microspectroscopy. Appl. Geochemistry 64, 107-117. doi:10.1016/j.apgeochem.2015.09.011

Sokol, E.., Kalugin, V.., Nigmatulina, E.., Volkova, N.., Frenkel, A.., Maksimova, N.., 2002. Ferrospheres from fly ashes of Chelyabinsk coals: chemical composition, morphology and formation conditions. Fuel 81, 867-876. doi:10.1016/S0016-2361(02)00005-4

Spadini, L., Bott, M., Wehrli, B., Manceau, A., 2003. Analysis of the major Fe bearing mineral phases in recent lake sediments by EXAFS spectroscopy. Aquat. Geochemistry 9, 1-17. doi:10.1023/B:AQUA.0000005608.69468.1e

Sterckeman, T., Douay, F., Proix, N., Fourrier, H., 2000. Vertical distribution of $\mathrm{Cd}, \mathrm{Pb}$ and $\mathrm{Zn}$ in soils near smelters in the North of France. Environ. Pollut. 107, 377-389. doi:10.1016/S0269-7491(99)00165-7

Sterckeman, T., Douay, F., Proix, N., Fourrier, H., Perdrix, E., 2002. Assessment of the contamination of cultivated soils by eighteen trace elements around smelters in the north of France. Water. Air. Soil Pollut. 135, 173-194. doi:10.1023/A:1014758811194

Trinkel, V., Mallow, O., Aschenbrenner, P., Rechberger, H., Fellner, J., 2016. Characterization of blast furnace sludge with respect to heavy metal distribution. Ind. Eng. Chem. Res. 55, 5590-5597. doi:10.1021/acs.iecr.6b00617

Trinkel, V., Mallow, O., Thaler, C., Schenk, J., Rechberger, H., Fellner, J., 2015. Behavior of chromium, nickel, lead, zinc, cadmium, and mercury in the blast furnace - A critical review of literature data and plant investigations. Ind. Eng. Chem. Res. 54, 1175911771. doi:10.1021/acs.iecr.5b03442

Valentim, B., Shreya, N., Paul, B., Gomes, C.S., Sant'Ovaia, H., Guedes, A., Ribeiro, J., Flores, D., Pinho, S., Suárez-Ruiz, I., Ward, C.R., 2016. Characteristics of ferrospheres in fly ashes derived from Bokaro and Jharia (Jharkand, India) coals. Int. J. Coal Geol. 153, 52-74. doi:10.1016/j.coal.2015.11.013

Vassilev, S. V., Vassileva, C.G., 1996. Mineralogy of combustion wastes from coal-fired power stations. Fuel Process. Technol. 47, 261-280. doi:10.1016/0378-3820(96)01016-8

Vdović, N., Billon, G., Gabelle, C., Potdevin, J.L., 2006. Remobilization of metals from slag and polluted sediments (Case Study: The canal of the Deûle River, northern France). Environ. Pollut. 141, 359-369. doi:10.1016/j.envpol.2005.08.034 
Wakeham, S.G., Forrest, J., Masiello, C.A., Gélinas, Y., Alexander, C.R., Leavitt, P.R., 2004. Hydrocarbons in Lake Washington sediments. A 25-year retrospective in an urban lake. Environ. Sci. Technol. 38, 431-439. doi:10.1021/es0343149

Wen, X.Y., Huang, C.M., Tang, Y., Gong-Bo, S.L., Hu, X.X., Wang, Z.W., 2014. Rare earth elements: a potential proxy for identifying the lacustrine sediment source and soil erosion intensity in karst areas. J. Soils Sediments 14, 1693-1702. doi:10.1007/s11368014-0928-y

Wilkin, R.T., Barnes, H.L.L., 1997. Formation processes of framboidal pyrite. Geochim. Cosmochim. Acta 61, 323-339. doi:10.1016/S0016-7037(96)00320-1

Xu, M., Yan, R., Zheng, C., Qiao, Y., Han, J., Sheng, C., 2004. Status of trace element emission in a coal combustion process: a review. Fuel Process. Technol. 85, 215-237. doi:10.1016/S0378-3820(03)00174-7

Zebracki, M., 2008. Devenir des polluants métalliques associés aux sédiments contaminés dans un cours d'eau en relation avec la dynamique sédimentaire. Université Paris-Sud XI, France.

Zeng, T., Arnold, W.A., Toner, B.M., 2013. Microscale characterization of sulfur speciation in lake sediments. Environ. Sci. Technol. 47, 1287-96. doi:10.1021/es303914q

Zhao, Y., Zhang, J., Sun, J., Bai, X., Zheng, C., 2006. Mineralogy, chemical composition, and microstructure of ferrospheres in fly ashes from coal combustion. Energy \& Fuels 20, 1490-1497. doi:10.1021/ef060008f 


\section{Supplementary Materials}

\section{Iron mineralogy as a fingerprint of former steelmaking activities in river sediments}

Hussein Jaafar Kanbar ${ }^{\mathrm{a}, \mathrm{b}, \mathrm{c}^{*}}$, Emmanuelle Montargès-Pelletier, ${ }^{\mathrm{a}, \mathrm{b}^{*}}$, Benoit Losson ${ }^{\mathrm{d}}$, Isabelle Bihannic $^{\mathrm{a}, \mathrm{b}}$, Renaud Gley ${ }^{\mathrm{a}, \mathrm{b}}$, Allan Bauer ${ }^{\mathrm{a}, \mathrm{b}}$, Frederic Villieras ${ }^{\mathrm{a}, \mathrm{b}}$, Luc Manceau ${ }^{\mathrm{d}}$, Antoine G El Samrani $^{\mathrm{c}}$, Veronique Kazpard ${ }^{\mathrm{c}}$, Laurence Mansuy-Huault ${ }^{\mathrm{a}, \mathrm{b}}$

\footnotetext{
${ }^{a}$ CNRS, LIEC (Laboratoire Interdisciplinaire des Environnements Continentaux), LTER Zone Atelier Moselle, 54500 Vandœuvre-lès-Nancy, France.

${ }^{\mathrm{b}}$ Université de Lorraine, LIEC (Laboratoire Interdisciplinaire des Environnements Continentaux), UMR 7360, 54500 Vandœuvre-lès-Nancy, France.

${ }^{\mathrm{c}}$ Research and Analysis Platform for Environmental Sciences (PRASE), Doctoral School of Sciences and Technology (EDST); Faculty of Sciences; Lebanese University, P.O. 5, Rafic Hariri Campus, 1003 Hadat, Lebanon.

${ }^{\mathrm{d}}$ Université de Lorraine, LOTERR, UFR SHS-Metz, Ile du Saulcy, CS60228, 57045 Metz cedex 01, France.

* Corresponding authors: Hsen.kanbar@gmail.com; emmanuelle.montarges@univ-lorraine.fr
} 
Supplementary Material 1: Aerial view of steelmaking facilities located in the very upstream zone of the dam in Moyeuvre-Grande. The image was taken approximately 32 years before the study (IGN 1982 - picture reference IGNF_PVA_1-0_1982-05-13_C3112-0011_1982_F3112-3512_0070). The image shows the Beth dam, and the locations of slagheaps, steel production, settling tank for wastewater (SWW), blast furnaces $(\mathrm{BF})$, iron mine $(\mathrm{Fe}$ mine), sintering plant and the Orne River.

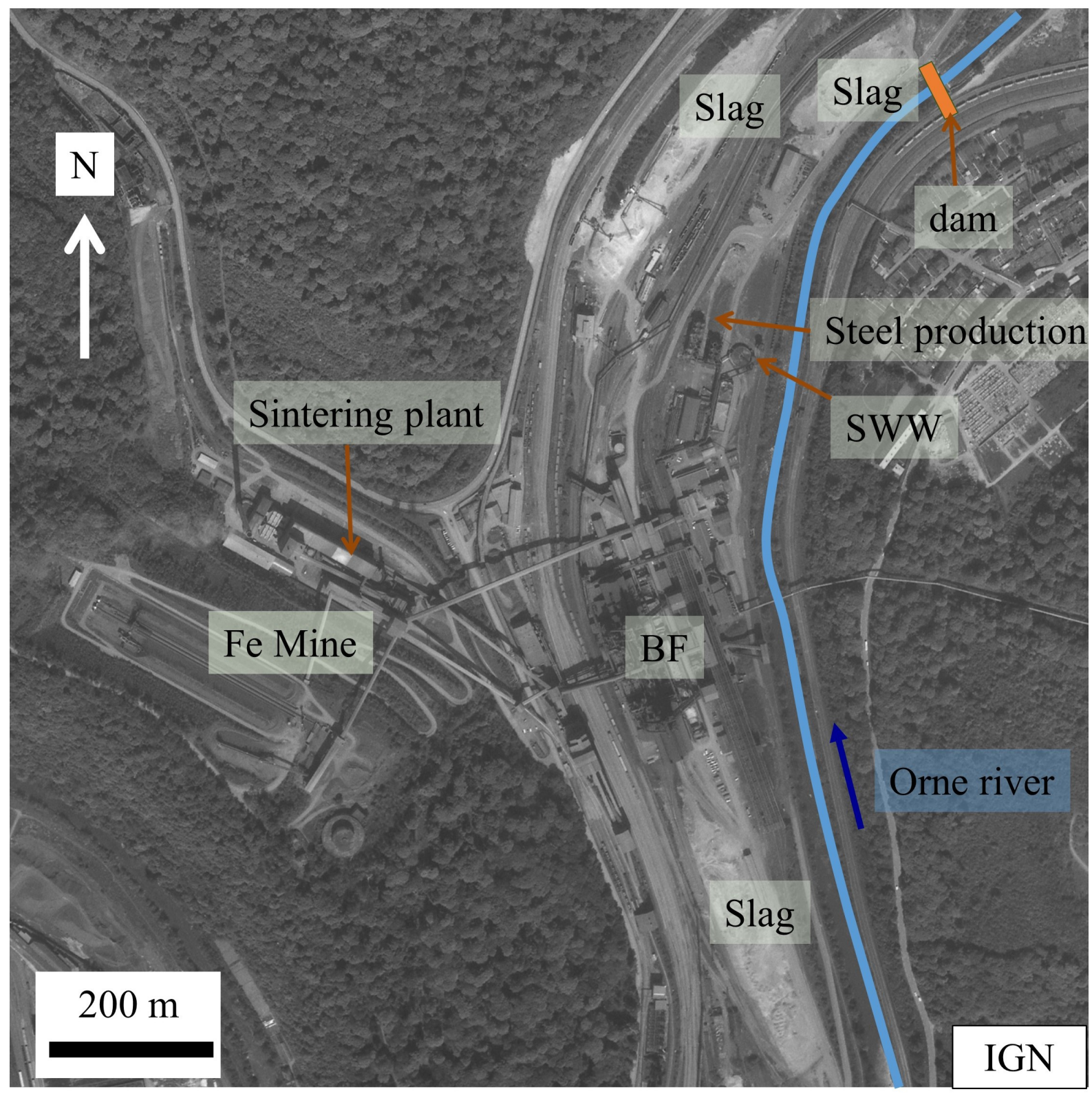


Supplementary Material 2: a: Variation of Fe (\%), Zn (g/Kg), Si (\%) and Ca (\%) contents (according to XRF and ICP data), and $\mathrm{D}_{50}$ values $(\mu \mathrm{m})$ in the vertical profile of BETH1402. b: Comparison between Si and Fe contents $(\%)$ in BETH1302 and BETH1402 cores (according to XRF data).

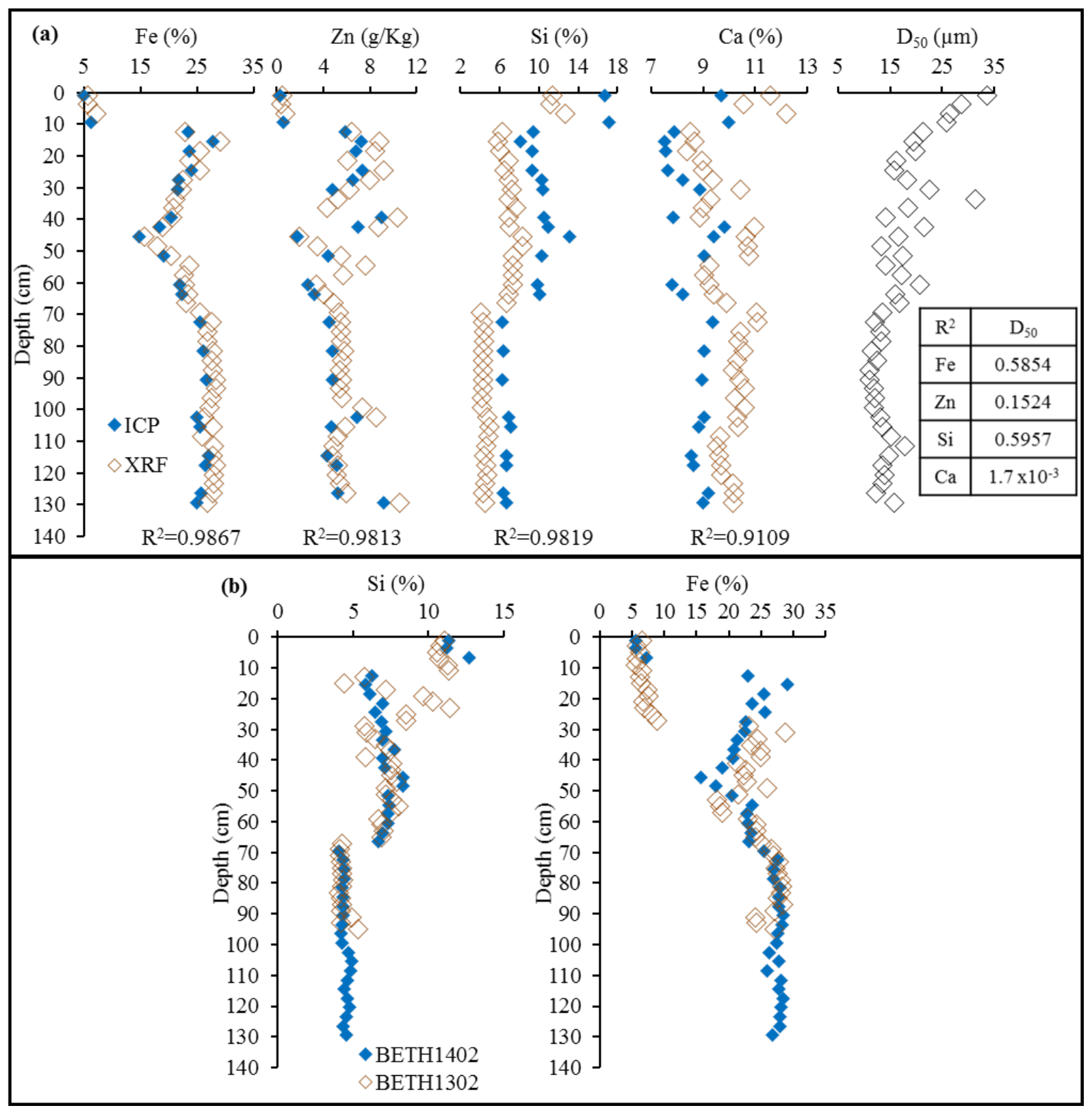

a: A comparison was made between the contents of the elements Fe, Zn, Si and Ca obtained from the XRF gun (Thermo Scientific Niton XL3t GOLDD+ Analyzer from GeoRessources laboratory, Vandœuvre-lès-Nancy, France) and ICP-OES (for Fe, Si and $\mathrm{Ca}$ ) and ICP-MS (for Zn). XRF measurements were performed on all the layers of BETH1402 core (as well as BETH1302 core). On the basis of XRF and grain size data, we selected several layers to determine their chemical composition by ICP-OES (for major elements) and ICP-MS (for minor elements), according to the procedures developed by Carignan et al., (2001). Fe contents were very alike between the semi-quantitative XRF measurements and ICP-OES, Zn contents were less alike, while Si and Ca XRF contents were slightly underestimated and overestimated, respectively. Nevertheless, the contents of the elements revealed by XRF and ICP were significantly correlated $\left(\mathrm{R}^{2}=0.9867\right.$ for $\mathrm{Fe}, 0.9813$ for $\mathrm{Zn}, 0.9819$ for $\mathrm{Si}$ and 0.9109 for $\mathrm{Ca}$; indicated at the bottom of the figures), and had similar trends in the vertical profile. Therefore, the $\mathrm{XRF}$ gun could be used as a reliable semi-quantitative technique to determine the chemical composition. As a result, we plotted the $\mathrm{Fe}$ and $\mathrm{Si}$ contents for all layers of BETH1302 and BETH1402 using the XRF data (elaborated in the below paragraph; part b). However, the chemical composition was not correlated to the particle size, as seen by poor correlations between $\mathrm{D}_{50}$ and the elements (see the table in the $\mathrm{D}_{50}$ figure). The poor or absence of correlation is most probably related to the complexity of the sediments; i.e. the contribution of various anthropogenic and lithogenic materials that had formed the sediments.

b: Fe and Si contents produced from the XRF gun for the layers of BETH1302 and BETH1402. The contents for both cores are superimposed and showed similar trends, especially in the deep layers. Consequently, the dating 
data of BETH1302 sediment core could be applied to BETH1402. It should be noted that the deposits of BETH1302 and BETH1402 also showed similarity in mineralogy (see SM 5 and fig. 5). 
Supplementary Material 3: Variation of the light lanthanides Ce, $\mathrm{Nd}$ and $\mathrm{Pr}$ (in $\mathrm{mg} / \mathrm{kg}$ ), major elements $\mathrm{K}, \mathrm{Al}, \mathrm{Mn}, \mathrm{Ti}$ and $\mathrm{Na}$ (in \%), and trace elements $\mathrm{Zr}, \mathrm{Mo}, \mathrm{Co}, \mathrm{Ni}, \mathrm{As}$ and $\mathrm{Cr}$ (in $\mathrm{mg} / \mathrm{kg}$ ) as a function of depth for the sediment layers of BETH1402 core. The units $0-11 \mathrm{~cm}, 11-44 \mathrm{~cm}, 47-68 \mathrm{~cm}$ and $68-131 \mathrm{~cm}$ are indicated by I, II, III and IV respectively.

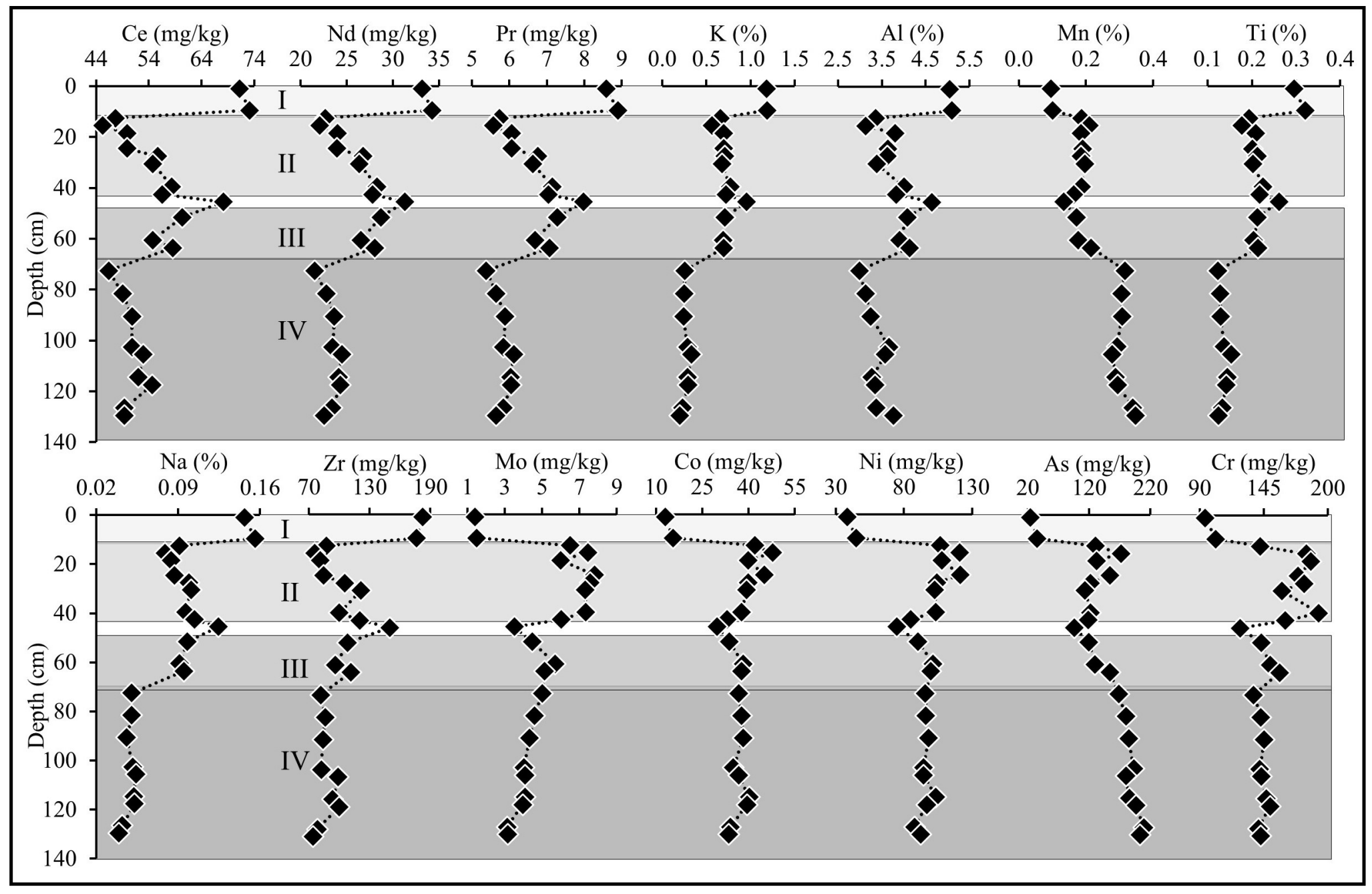


Supplementary Material 4: Pearson correlation coefficient for the elements in the sediment layers of BETH1402 core ( $\mathrm{n}=23)$.

\begin{tabular}{|c|c|c|c|c|c|c|c|c|c|c|c|c|c|c|c|c|c|c|c|c|c|c|}
\hline & & $\mathrm{Al}$ & $\mathrm{Ca}$ & $\mathrm{K}$ & $\mathrm{Na}$ & $\mathrm{Ti}$ & $\mathrm{La}$ & $\mathrm{Ce}$ & $\operatorname{Pr}$ & $\mathrm{Nd}$ & $\mathrm{Zr}$ & $\mathrm{Zn}$ & $\mathrm{Pb}$ & V & $\mathrm{Fe}$ & $\mathrm{S}$ & As & $\mathrm{Mn}$ & Mo & $\mathrm{Ni}$ & Co & $\mathrm{Cr}$ \\
\hline \multirow{2}{*}{$\mathrm{Si}$} & PCC & $.898^{* *}$ & .295 & $.968^{* *}$ & $.979^{* *}$ & $.981^{* *}$ & $.956^{* *}$ & $.885^{* *}$ & $.938^{* * *}$ & $.923^{* *}$ & $.913^{* *}$ & $-.569^{* *}$ & $-.819^{* *}$ & $-.849^{* *}$ & $-.960^{* *}$ & $-.510^{*}$ & $-.969^{* *}$ & $-.912^{* *}$ & -.238 & $-.695^{* *}$ & $-.723^{* *}$ & -.390 \\
\hline & $P$ & .000 & .171 & .000 & .000 & .000 & .000 & .000 & .000 & .000 & .000 & .005 & .000 & .000 & .000 & .013 & .000 & .000 & .275 & .000 & .000 & .066 \\
\hline \multirow{2}{*}{$\mathrm{Al}$} & PCC & & .371 & $.832^{* *}$ & $.824^{* *}$ & $.873^{* *}$ & $.940^{* *}$ & $.926^{* *}$ & $.934^{* *}$ & $.926^{* *}$ & $.853^{* *}$ & $-.555^{* *}$ & $-.659^{* *}$ & $-.637^{* *}$ & $-.921^{* *}$ & $-.553^{* *}$ & $-.811^{* *}$ & $-.741^{* *}$ & $-.484^{*}$ & $-.773^{* *}$ & $-.815^{* *}$ & $-.486 *$ \\
\hline & $P$ & & .082 & .000 & .000 & .000 & .000 & .000 & .000 & .000 & .000 & .006 & .001 & .001 & .000 & .006 & .000 & .000 & .019 & .000 & .000 & .019 \\
\hline \multirow[b]{2}{*}{$\mathrm{Ca}$} & PCC & & & .086 & .181 & .154 & .360 & $.502^{*}$ & $.428^{*}$ & $.434^{*}$ & $.557^{* *}$ & $-.473^{*}$ & -.177 & .099 & $-.510^{*}$ & $-.521^{*}$ & -.273 & .000 & $-.725^{* *}$ & $-.795^{* *}$ & $-.757^{* *}$ & $-.752 * *$ \\
\hline & $P$ & & & .696 & .409 & .482 & .091 & .015 & .042 & .039 & .006 & .023 & .418 & .655 & .013 & .011 & .207 & .999 & .000 & .000 & .000 & .000 \\
\hline \multirow{2}{*}{ K } & PCC & & & & $.990^{* * *}$ & $.992^{* * *}$ & $.907^{* *}$ & $.796^{* *}$ & $.877^{* * *}$ & $.860^{* *}$ & $.814^{* * *}$ & $-.472^{*}$ & $-.839^{* *}$ & $-.937^{* *}$ & $-.872^{* *}$ & -.387 & $-.952^{* *}$ & $-.976^{* *}$ & -.030 & $-.511^{*}$ & $-.545^{* *}$ & -.196 \\
\hline & $P$ & & & & & .000 & .000 & .000 & .000 & .000 & .000 & .023 & .000 & .000 & .000 & .068 & .000 & .000 & .893 & .013 & .007 & .371 \\
\hline \multirow{2}{*}{$\mathrm{Na}$} & PCC & & & & & $.987^{* *}$ & $.923^{* * *}$ & $.824^{* *}$ & $.898^{* *}$ & $.883^{* * *}$ & $.859^{* *}$ & $-.521^{*}$ & $-.858^{* *}$ & $-.919^{* *}$ & $-.894^{* *}$ & $-.441^{*}$ & $-.966^{* *}$ & $-.965^{* *}$ & -.065 & $-.560^{* *}$ & $-.583^{* *}$ & -.257 \\
\hline & $P$ & & & & & .000 & .000 & .000 & .000 & .000 & .000 & .011 & .000 & .000 & .000 & .035 & .000 & .000 & .767 & .006 & .003 & .236 \\
\hline \multirow{2}{*}{ Ti } & PCC & & & & & & $.942^{* *}$ & $.848^{* *}$ & $.918^{* * *}$ & $.903^{* *}$ & $.852^{* *}$ & $-.507^{*}$ & $-.837^{* *}$ & $-.893^{* *}$ & $-.899^{* *}$ & $-.429^{*}$ & $-.949^{* *}$ & $-.955^{* *}$ & -.114 & $-.574^{* *}$ & $-.606^{* *}$ & -.245 \\
\hline & $P$ & & & & & & .000 & .000 & .000 & .000 & .000 & .014 & .000 & .000 & .000 & .041 & .000 & .000 & .604 & .004 & .002 & .260 \\
\hline \multirow{2}{*}{$\mathrm{La}$} & PCC & & & & & & & $.971^{* *}$ & $.987^{* *}$ & $.982^{* *}$ & $.942^{* *}$ & $-.645^{* *}$ & $-.828^{* *}$ & $-.722^{* *}$ & $-.939^{* *}$ & $-.618^{* *}$ & $-.901^{* *}$ & $-.837^{* *}$ & -.349 & $-.732^{* *}$ & $-.751^{* *}$ & $-.440 *$ \\
\hline & $P$ & & & & & & & .000 & .000 & .000 & .000 & .001 & .000 & .000 & .000 & .002 & .000 & .000 & .103 & .000 & .000 & .036 \\
\hline \multirow{2}{*}{$\mathrm{Ce}$} & $\mathrm{PCC}$ & & & & & & & & $.982^{* *}$ & $.984^{* *}$ & $.950^{* *}$ & $-.683^{* *}$ & $-.760^{* *}$ & $-.558^{* *}$ & $-.920^{* *}$ & $-.716^{* *}$ & $-.821^{* *}$ & $-.714^{* *}$ & $-.500^{*}$ & $-.815^{* *}$ & $-.822^{* *}$ & $-.539 * *$ \\
\hline & $P$ & & & & & & & & .000 & .000 & .000 & .000 & .000 & .006 & .000 & .000 & .000 & .000 & .015 & .000 & .000 & .008 \\
\hline \multirow{2}{*}{$\operatorname{Pr}$} & PCC & & & & & & & & & $.999^{* *}$ & $.943^{* *}$ & $-.636^{* *}$ & $-.804^{* *}$ & $-.676^{* *}$ & $-.942^{* *}$ & $-.669^{* *}$ & $-.885^{* *}$ & $-.807^{* *}$ & -.382 & $-.765^{* *}$ & $-.784^{* *}$ & $-.444 *$ \\
\hline & $P$ & & & & & & & & & .000 & .000 & .001 & .000 & .000 & .000 & .000 & .000 & .000 & .072 & .000 & .000 & .034 \\
\hline \multirow{2}{*}{$\mathrm{Nd}$} & PCC & & & & & & & & & & $.938^{* *}$ & $-.636^{* *}$ & $-.801^{* *}$ & $-.652^{* *}$ & $-.929^{* *}$ & $-.683^{* *}$ & $-.869^{* *}$ & $-.792^{* *}$ & -.382 & $-.760^{* *}$ & $-.777^{* *}$ & $-.438 *$ \\
\hline & $P$ & & & & & & & & & & .000 & .001 & .000 & .001 & .000 & .000 & .000 & .000 & .072 & .000 & .000 & .037 \\
\hline \multirow{2}{*}{$\mathrm{Zr}$} & PCC & & & & & & & & & & & $-.737^{* *}$ & $-.806^{* *}$ & $-.610^{* *}$ & $-.943^{* *}$ & $-.664^{* *}$ & $-.876^{* *}$ & $-.741^{* *}$ & $-.469^{*}$ & $-.841^{* *}$ & $-.832^{* *}$ & $-.599 * *$ \\
\hline & $P$ & & & & & & & & & & & .000 & .000 & .002 & .000 & .001 & .000 & .000 & .024 & .000 & .000 & .003 \\
\hline \multirow{2}{*}{$\mathrm{Zn}$} & PCC & & & & & & & & & & & & $.724^{* *}$ & .286 & $.627^{* *}$ & $.631^{* *}$ & $.563^{* *}$ & $.416^{*}$ & $.600^{* *}$ & $.694^{* *}$ & $.649^{* *}$ & $.759 * *$ \\
\hline & $P$ & & & & & & & & & & & & .000 & .186 & .001 & .001 & .005 & .048 & .002 & .000 & .001 & .000 \\
\hline \multirow{2}{*}{$\mathrm{Pb}$} & PCC & & & & & & & & & & & & & $.734^{* *}$ & $.753^{* *}$ & $.488^{*}$ & $.865^{* *}$ & $.838^{* *}$ & .072 & $.487^{*}$ & $.487^{*}$ & .304 \\
\hline & $P$ & & & & & & & & & & & & & .000 & .000 & .018 & .000 & .000 & .743 & .018 & .018 & .159 \\
\hline \multirow{2}{*}{ V } & PCC & & & & & & & & & & & & & & $.706^{* *}$ & .160 & $.870^{* *}$ & $.956^{* *}$ & -.224 & .272 & .311 & .011 \\
\hline & $P$ & & & & & & & & & & & & & & .000 & .466 & .000 & .000 & .304 & .209 & .149 & .960 \\
\hline \multirow{2}{*}{$\mathrm{Fe}$} & PCC & & & & & & & & & & & & & & & $.600^{* *}$ & $.930^{* *}$ & $.789^{* *}$ & $.453^{*}$ & $.856^{* *}$ & $.880^{* *}$ & $.576^{* *}$ \\
\hline & $P$ & & & & & & & & & & & & & & & .002 & .000 & .000 & .030 & .000 & .000 & .004 \\
\hline \multirow[b]{2}{*}{ S } & PCC & & & & & & & & & & & & & & & & $.455^{*}$ & .289 & $.507^{*}$ & $.641^{* *}$ & $.625^{* *}$ & $.582^{* *}$ \\
\hline & $P$ & & & & & & & & & & & & & & & & .029 & .180 & .014 & .001 & .001 & .004 \\
\hline & PCC & & & & & & & & & & & & & & & & & $.921^{* *}$ & .153 & $.648^{* *}$ & $.676^{* *}$ & .357 \\
\hline As & $P$ & & & & & & & & & & & & & & & & & .000 & .487 & .001 & .000 & .095 \\
\hline $\mathrm{Mn}$ & PCC & & & & & & & & & & & & & & & & & & -.096 & .392 & $.420^{*}$ & .098 \\
\hline Mn & $P$ & & & & & & & & & & & & & & & & & & .662 & .064 & .046 & .658 \\
\hline & PCC & & & & & & & & & & & & & & & & & & & $.813^{* *}$ & $.786^{* *}$ & $.871 * *$ \\
\hline Mo & $P$ & & & & & & & & & & & & & & & & & & & .000 & .000 & .000 \\
\hline $\mathrm{Ni}$ & PCC & & & & & & & & & & & & & & & & & & & & $.989^{* *}$ & $.834 * *$ \\
\hline $\mathbf{N} 1$ & $P$ & & & & & & & & & & & & & & & & & & & & .000 & .000 \\
\hline $\mathrm{C}$ & PCC & & & & & & & & & & & & & & & & & & & & & $.796 * *$ \\
\hline 6 & $P$ & & & & & & & & & & & & & & & & & & & & & .000 \\
\hline
\end{tabular}

PCC: Pearson correlation coefficient, same as Pearson's R.

$P: P$ value. The $P$ value is the probability of finding the observed results when the null hypothesis $\left(\mathrm{H}_{0}\right)$ is true. $\mathrm{H}_{0}$ : there does not exist a correlation between $\mathrm{X}$ and $\mathrm{Y}$.

$* *$ : Correlation is significant at the 0.01 level (2-tailed).

*: Correlation is significant at the 0.05 level (2-tailed). 
Supplementary Material 5: XRD patterns of BETH1302 sediments showing minerals and diffraction line trends similar to BETH1402 sediments (fig. 5). The XRD patterns of BETH1302 layers showed, as a function of depth: i. an increase of the $7.14 \AA$ diffraction line, which was assigned to a newly formed aluminosilicate (with basal plane 001 of phyllosilicate) and was particularly enriched in iron, ii. an increase of goethite peaks at 4.18 and $2.69 \AA$, and iii. a decrease of hkl diffraction lines of phyllosilicates at 4.47 and $2.57 \AA$. The blue diffractograms represent sediment samples of lithogenic nature, while the black diffractograms belong to the materials mainly composed of steelmaking waste.

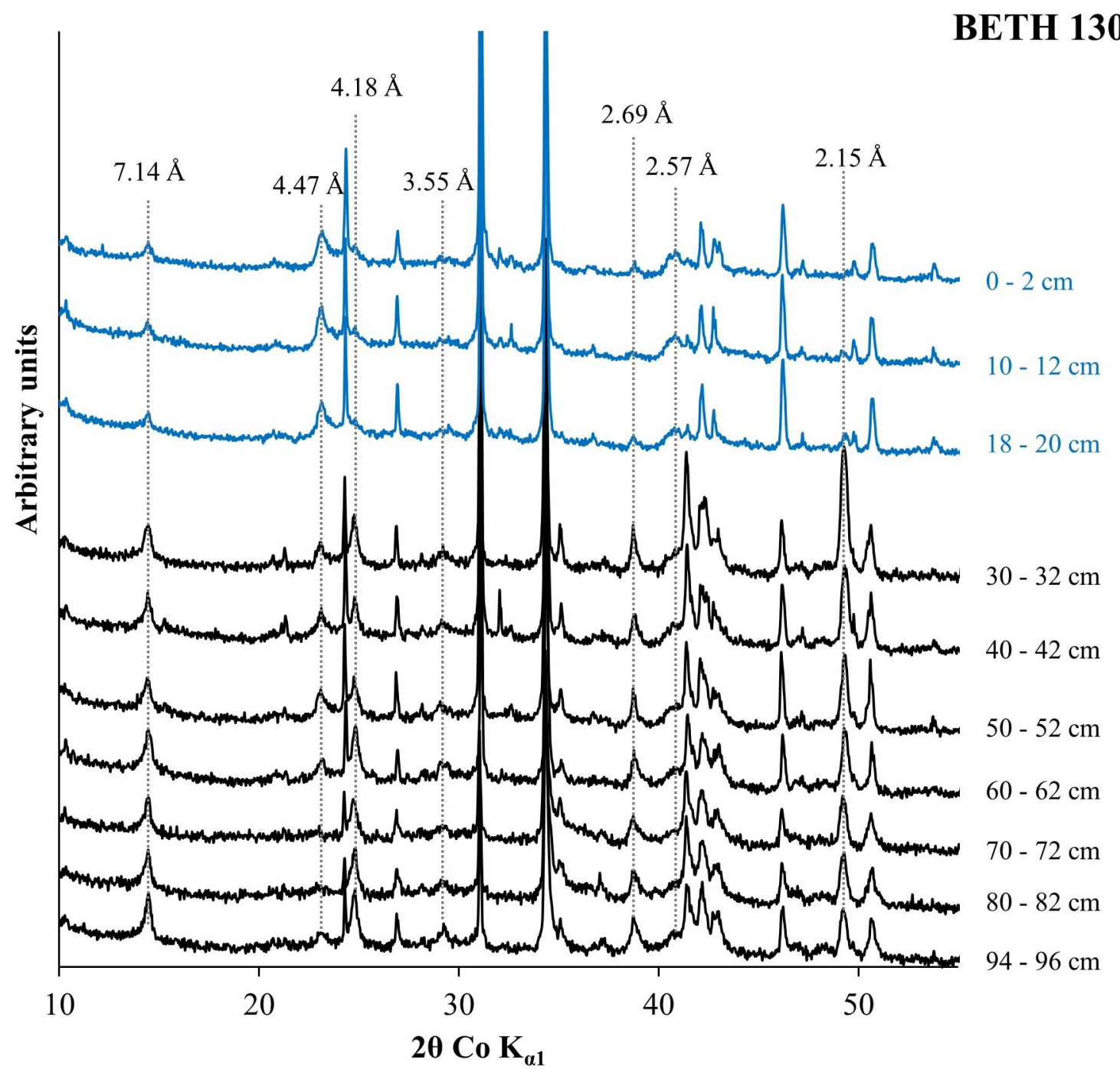


Supplementary Material 6: a: XRD pattern of "Minette" iron ore; marked in red are the diffraction lines of goethite; b: SEM BSE micro-image of a weathered iron ooid seen in the sediments of the Orne River; c: TEM micro-image of goethite nanogranules of the Minette ore, $\mathrm{d}$ : corresponding EDX spectrum, e: table summarizing the TEM-EDX data and f: SAED pattern. Asterisks on the EDX spectra (d) indicate the emission lines of copper, which are due to the contribution of the TEM grid, a carbon coated copper grid.
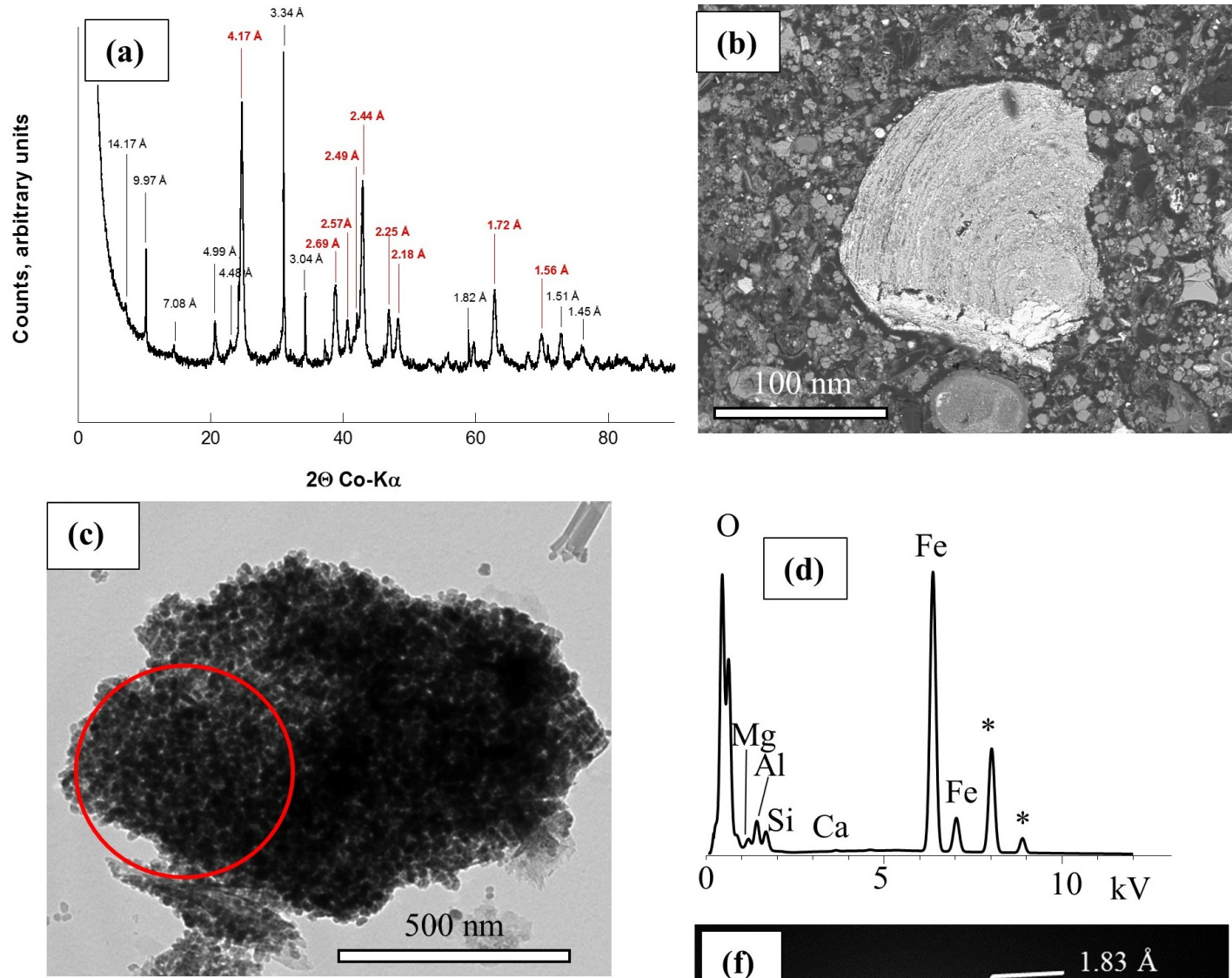

\begin{tabular}{|cccc|}
\cline { 1 - 3 }$(\mathbf{e})$ & $\begin{array}{c}\mathrm{K} \\
\text { factor }\end{array}$ & $\begin{array}{c}\text { Atomic } \\
\text { percentage }\end{array}$ & $\begin{array}{c}\text { Emission } \\
\text { line }\end{array}$ \\
\cline { 1 - 3 } $\mathrm{O}$ & 1.7628 & 67.4 & $\mathrm{~K} \alpha$ \\
\cline { 1 - 3 } $\mathrm{Mg}$ & 0.7624 & 1.1 & $\mathrm{~K} \alpha$ \\
\hline $\mathrm{Al}$ & 0.7314 & 2.7 & $\mathrm{~K} \alpha$ \\
\hline $\mathrm{Si}$ & 0.6924 & 1.8 & $\mathrm{~K} \alpha$ \\
\hline $\mathrm{P}$ & 0.7440 & $<0.1$ & $\mathrm{~K} \alpha$ \\
\hline $\mathrm{Ca}$ & 0.7732 & $<0.1$ & $\mathrm{~K} \alpha$ \\
\hline $\mathrm{Fe}$ & 1.0 & 27 & $\mathrm{~K} \alpha$ \\
\hline
\end{tabular}

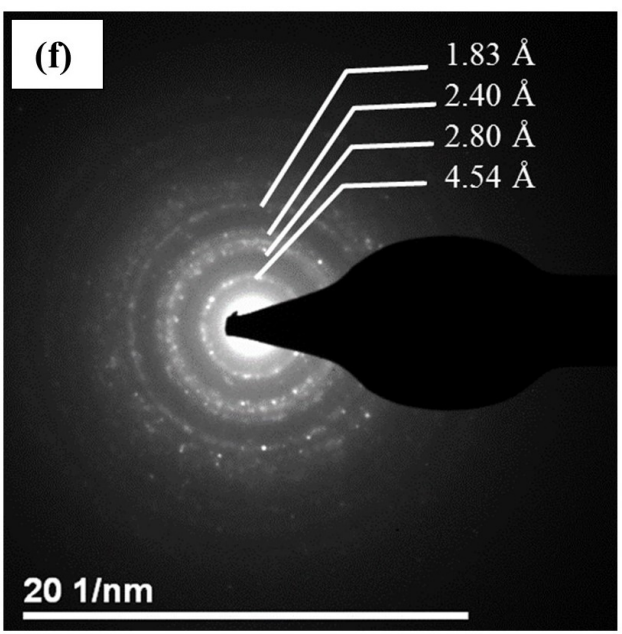

TEM micro-images of the Minette ore showed the predominance of circular Fe-bearing nanoparticles (SM 6 c). EDXS revealed that those nanoparticles had an O:Fe ratio of $2.1 \pm 0.2$ (table 1 in the main text), indicating Feoxyhydroxide $(\mathrm{FeOOH})$. Furthermore, since XRD patterns of the "Minette" sample showed diffraction lines for goethite (mainly 4.17 and $2.44 \AA$ ), these FeOOH particles were identified as goethite particles (SM 5 a). Finally, TEM SAED on aggregates provide a typical pattern of polycrystalline material (SM $5 \mathrm{f}$ ). Electron diffraction resulted in several rings that were assigned to diffraction distances. Several aggregates were tested and all provided similar SAED patterns. Also a similar electron diffraction pattern was obtained from $\mathrm{Fe}$ oxyhydroxides particles in Beth sediments. From particle size and morphology, EDXS and SAED data, we could demonstrate that the nanoparticles detected in BETH1402 sediments (Figure 8a in the main text), are fingerprints of the Minette ore that was used in steelmaking in Lorraine. 
Supplementary Material 7: TEM micro-image of silico-calcic glass phases that were detected in the sediments of BETH1402 with a corresponding EDX spectrum.
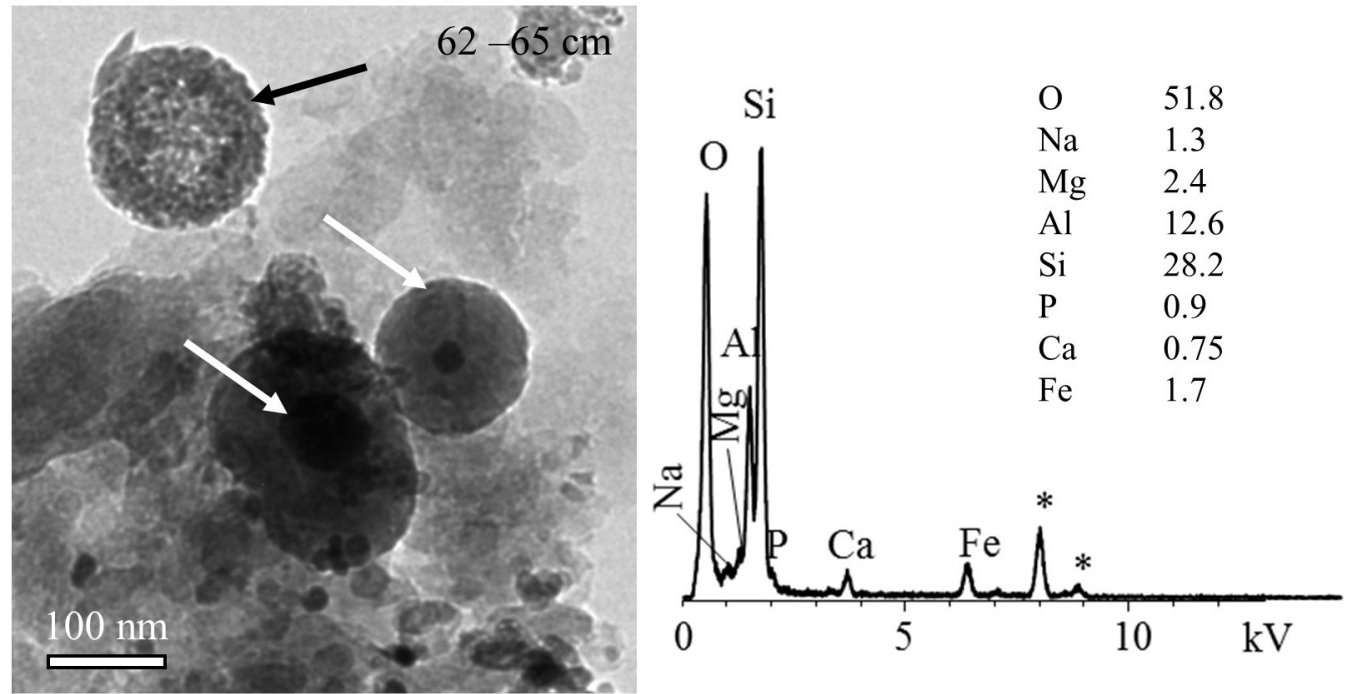